Article

\title{
Exploring the Influence of Personal Motivations, Beliefs and Attitudes on Students' Post-Graduation Migration Intentions: Evidence from Three Major Romanian Universities
}

\author{
Aurelian-Petruș Plopeanu ${ }^{1}\left(\mathbb{D}\right.$, Daniel Homocianu ${ }^{2, *}$, Alin Adrian Mihăilă ${ }^{3}$, \\ Emil Lucian Crișan ${ }^{3}$, Gabriela Bodea ${ }^{3}$, Renate-Doina Bratu ${ }^{4}$ and Dinu Airinei ${ }^{2}$ \\ 1 Department of Interdisciplinary Research-Humanities and Social Sciences, Alexandru Ioan Cuza \\ University of lași, Lascar Catargi Street 54, Iași 700506, Romania; aplopeanu@gmail.com \\ 2 Department of Research, Faculty of Economics and Business Administration, Alexandru Ioan Cuza \\ University of Iași, Carol I Boulevard 22, Iași 700505, Romania; adinu@uaic.ro \\ 3 Faculty of Economics and Business Administration, Babes-Bolyai University, Teodor Mihali Street 58-60, \\ Cluj 400028, Romania; alin.mihaila@econ.ubbcluj.ro (A.A.M.); emil.crisan@econ.ubbcluj.ro (E.L.C.); \\ gabriela.bodea@econ.ubbcluj.ro (G.B.) \\ 4 Faculty of Economics, Lucian Blaga University of Sibiu, Sibiu 550024, Romania; renate.bratu@ulbsibiu.ro \\ * Correspondence: dan.homocianu@gmail.com; Tel.: +40-232-20-1413
}

Received: 29 September 2018; Accepted: 25 October 2018; Published: 1 November 2018

Featured Application: Starting from answers to a questionnaire survey from three major Romanian universities, this study investigates the post-graduation migration intentions of students in economics, in the context of Europe's demographic decline and Romanian yearly increases of out-migration flows to Western countries. It was found that recognition of personal value and individual freedom are key positive factors. These findings could be strategic to contribute to local development policies for the preservation of human social capital and above all of the young graduates.

\begin{abstract}
Nowadays, when there is much concern about the demographic decline of Europe and the stringent need for public policies that support intelligent, sustainable, and inclusive growth in times of population ageing, this study aims to validate several hypotheses regarding the post-graduation migration intentions of students in economics. To analyse these intentions in the context of Romanian yearly increases of out-migration flows to Western countries, the answers to the questionnaire used for this study were obtained from three important Romanian universities. Using georeferencing, neural networks-based data mining, and two types of regression analysis, the results represent a relevant contribution to the limited body of literature. They empirically show that motivations and attitudes towards a meritocratic environment for professional advancement, and individual freedom are positive key factors for students' migration intentions after graduation. In addition, the paper emphasises the secondary role of religiosity and intergenerational transfer of parental migration experience. It also finds that, although the income level has some influence on these intentions, its role is far less important than the one emphasised in the specific literature, which leads us to the conclusion that non-economic motivations matter more than the economic ones for the potential decision to migrate after graduation.
\end{abstract}

Keywords: migration intentions; personal value recognition; family and individual features; georeferencing; data mining; regression analysis 


\section{Introduction}

This paper addresses a real problem for the sustainable future of European economies and societies, namely, the accelerated population decrease. In Romania's case, the outward migration in the last decades represented approximately $50 \%$ of this decline [1]. A recent study conducted by World Bank [2] presents the real proportion of this demographic decline: between 2001 and 2017, the Romanian population recorded a decline of around 3.2 million people, due to the decrease in fertility and the increase in mortality and migration. The same study stresses that, in 2010, Romania was ranked 10th when it came to labour force drain in G20 countries, from which $26.6 \%$ was represented by the category of highly educated. In the context of a more demanding economy, the lack of such a precious human capital is extremely difficult to compensate, especially when Romania has the lowest level of tertiary education attainment in the European Union.

In this context, migration intentions among post-graduate students are a challenging $[3,4]$ and niche topic [5] in literature. The effects for the donor country could be negative. In this direction, "the emigration of skilled workers is usually blamed for depriving developing countries of one of their scarcest sources, human capital" [6] (p. 2). These intentions, among Romanian students, are an essential indicator for further understanding their future interactions with the labour market and, even more, their potential migration behaviours in the future [7] (p. 83).

This study is one of the very few in the literature which aims to offer an in-depth perspective about post-graduation migration intentions of students in economics from the universities from Iasi, Cluj-Napoca, and Sibiu. Although the specific body of research offers a long list of variables that influences the willingness to migrate abroad, the novelty of our paper is twofold: firstly, it is given by the regional specificities of the students belonging to a certain university and, secondly, it offers a unique combination of not necessarily pecuniary factors that received little evidence in the literature. Therefore, our need to understand the reasons why they intend to migrate after graduation was an incentive to study this particular topic within a specific sample. Also, we have tried to explain which variables matter the most for the likelihood to migrate after graduation: either the personal fulfilment through migration (personal value recognition), the degree of individual freedom, the level of religiosity, the previous educational performance, or the parental role models and migration experiences abroad? Moreover, understanding the common factors behind the intentions to migrate for the students from all three universities, and others that may greatly shape the migration trajectories do not have the same magnitudes and significance, when taking into consideration our three distinct samples. Hence, emphasising that these students may have some different inputs that they could take into consideration, when it comes to mobility proclivity, is a valuable perspective that demonstrates those particular features, which could be explained from many angles.

\section{Literature Review}

The decision to take into consideration students' intentions to migrate is based on previous findings which demonstrate their high mobility behaviour [8], due to lesser familial constraints [9]. Especially after the 2008 economic crisis, the migration levels among young individuals increased almost all over Europe [10]. In the case of the Romanian economy, the past difficulties faced by young adults to find proper jobs, according to their educational background and vocation, constitute a trigger that determines them to leave their country of origin.

Many studies demonstrate that these highly educated students could be a valuable resource for innovation and economic growth [11,12]. It is considered that "the links between migration and internationalisation of higher education are reciprocal in that migration strategies and policies encourage and facilitate the internationalisation of higher education while, at the same time, they are becoming increasingly dependent on, that process" [13] (p. 117). Also, a large proportion of these intentions are focused towards richer EU member states, therefore, the very possible impact on these countries' competitiveness is extremely high and, also, with positive effects on the whole European economy $[10,14]$. He et al. [15] emphasise the impact of retaining foreign high-skilled labour force 
on recipient country's demography, regional disparities, and economic development. Therefore, macroeconomic stability has an important influence towards these intentions to migrate [16], since young adults record high unemployment rates in many European countries. Moreover, the regional disparities could contribute to the willingness to migrate abroad [17].

Many scholars have highlighted the dilemma whether the future intentions to migrate could predict a real decision $[4,18,19]$. Besides the impossibility to even intentions and facts, migration intentions are important features emphasised in the literature [20], because the associated motivations and perspectives could start and develop a highly dynamic process. In our opinion, and based on previous research [21], migration intentions are a credible predictor and trigger for real future migration. The decision to switch from intentions to migrate, to an actual decision to leave the country of origin, is based on the same category of factors [18,22]. In conclusion, "migration intentions data holds advantages connected to both substantive and practical issues" [23] (p. 120).

The mainstream theory regarding international migration is mainly explained using the linear and behavioural "push-and-pull" model [24]. The main idea is that "push factors", which are causes that exist in home countries, are interlinked with superior "pull factors," that exist in the receiving countries [25]. Our intention was not to stick to the limitations of the "push-and-pull" model, and stress a deeper understanding of the factors that may affect the willingness to migrate abroad of post-graduate students from economics profiles. In this direction, our desire was to check whether the economic "push" factors are the most important ones, or the only ones that matter the most.

The main focus on the post-graduation intentions-to-leave the country of origin, in the case of students in economics, is considered relevant for different reasons. Firstly, the migration of highly skilled individuals could launch pervasive provocations in terms of economic, political, social and demographic changes [26]. Secondly, the real migration phenomenon could be understood, at least partially, in terms of previous manifested intentions to leave the country of origin. As shown in other studies $[27,28]$, the level of education is an important variable that may influence the decision to migrate. Therefore, the selection of our sample among students from economics faculties was not made by chance, but we took into consideration the fact that these young adults may have chosen to pursue higher education studies for more and better opportunities on a labour market mostly from Western Europe.

Our results constitute important prerequisites for criticising the neoclassical theory and its subsequent updates, according to which the economic factors are essential variables that influence the migration phenomenon. Also, we do not agree that non-economic factors complement the economic ones, therefore being considered "second-hand" explanations of the migration phenomenon [29]. Our quasi-heterodox perspective improves an important part of the literature by taking into consideration the non-pecuniary factors that, in our case, are the most important reasons behind the future decision to leave the country of origin for a better life.

\section{Main Hypotheses}

A large body of literature provides clear evidence that economic factors are the most used ones to explain the migration phenomenon, but they are an easy and limited attempt and, what really matters in many cases, are the non-economic ones, such as the psychological, personal, and social inputs [3,30,31]. Cebula [32] (p. 267) stressed that the analysis of this phenomenon based solely on economic factors is not enough, therefore, it must be augmented by taking into consideration the non-economic ones.

Especially when it comes to future highly skilled workers, they will be less constrained by economic reasons to migrate, but by more profound ones. That is why "immaterial" factors, including the desire for professional advancement and specific opportunities [33], superior standards of living [34,35], the sociocultural background abroad [36], and better institutions in the destination country [37], have an important impact on the likelihood to migrate abroad. Moreover, it is considered that "there is extensive evidence thereof, that mobility between two countries with different mean 
levels of real wages may remain low when a considerable improvement in the standard of living and quality of life in the poorer country is expected" [38] (p. 1631).

The most important motivation for our article was to test and validate a series of hypothesis in order to identify the main factors that are responsible for students' intentions to leave Romania after their graduation. We are fully aware that there are many other influencing factors on migration intentions which are interconnected and, therefore, difficult to measure. Taking into consideration all these previous arguments, we expect that

Hypothesis 1 (H1). The students who put a great emphasis not necessarily on pecuniary motivations, such as personal value recognition, individual liberty, low interpersonal trust, and agreeableness, are more likely to migrate rather than stay in the country of origin.

First of all, we assume that the recognition of personal value is not necessarily pecuniary, because it covers mostly superior needs deeply related to personal fulfilment, such as the need for meritocratic environments, better systems and infrastructures to support the success and efficiency of pursuing career paths, equal opportunities for career advancement for all competitors, etc. It is emphasised that young adults are mainly motivated by career opportunities in their decision to leave their country of origin but, also, self-development is an important reason why people often choose to migrate [39]. In the same direction, taking into consideration the migration of Spanish highly skilled labour force after the 2008 crisis, the process was accompanied by different non-pecuniary triggers, such as the negative attitude towards a society where meritocracy is not the piece that fits the societal "puzzle", where corruption is endemic and overspread, where the political system is cumbersome and incapable of making healthy and efficient decisions, where the lack of predictability regarding job security is the basic rule, where the low standards of working conditions are daunting, where the future of the socioeconomic elements produces anxiety, and where the "lack of civility, disorganization and apathy" are pulling factors [40] (pp. 259-261).

Moreover, it is considered that a political regime which stimulates economic freedom also offers the possibility to exert individual freedom. Therefore, several scholars point out that higher levels of economic freedom are the main drivers for the willingness to migrate abroad [41,42]. In the case of United States of America, the individuals migrate in those states that record higher levels of economic freedom [43,44]. For the Albanians, Papapanagos and Sanfey (2001) emphasise that the higher the individuals' preferences for the free markets, the higher their intentions to migrate in other countries.

Tilly (2007), using his study results [45], concluded that the students who manifest a great sense of interpersonal trust have a low proclivity to migrate abroad because of belonging to social networks of mutual trust, which act as institutions that operate in order to fulfil duties and overcome obstacles.

Frieze et al. (2006) demonstrated that personality affects young people's mobility decisions [46]. Others [47] have found that openness to experience is a personality trait that has an essential role on the skilled migrants' intentions to leave their native country. By contrast, regarding agreeableness, this personality trait decreases the likelihood to migrate in the future [48-50], because this personal quality creates powerful emotional attachments with close people [51]. Moreover, other scholars [52] have not found any connection between this variable and the intention to migrate, while others [53] demonstrated a positive relationship, but only in the situation when the migration was achieved.

Hypothesis 2 (H2). Individuals with lower levels of external religiosity (frequency of participation at religious services) and higher ones for internal religiosity (personal belief in God) are more likely to leave the country of origin.

Docquier et al., analysing the intentions to migrate, found that individuals with lower levels of religiosity are more likely to leave these countries and move abroad for a better life [54]. Van Dijck, Feijten, and Boyle have come to the conclusion that, in comparison with non-religious individuals, those who manifest higher religiosity have a lower inclination towards geographical mobility, especially 
due to a certain type of capital that is embedded with religious features by simply belonging to a certain denomination [55] (p. 22). Other studies emphasise that, using different religiosity scales, compared with the natives, the immigrants present higher religiosity levels [56] (p. 20). Hoffman, Marsiglia, and Ayers made a clear distinction between the influence of internal and external religiosity towards the migration intentions, finding that an increased level of external religiosity among them has a negative effect on the desire to leave the country and move to the United States. By contrast, a higher internal religiosity has a positive influence on their migration intentions because of a sense of divine protection that will ease the integration in a foreign society [57].

Hypothesis 3 (H3). The students who benefit from intergenerational transmission of past migration experience from their parents and have higher educated parents are more likely to migrate after graduation.

Massey (1990) and Menjívar (2000) demonstrate that the migration intentions could be influenced by relatives and/or friends who already migrated abroad [58,59]. Hence, "family migration capital" or the (positive) transmission of migration experiences abroad from parents to their children "reduces the non-pecuniary (psychological/psychic) costs of migration. Attitudes and stories about past migration could be passed from one generation to another, and migration in such families could be viewed as a less risky, more rewarding and enriching enterprise, compared to families without such experience" [23] (p. 119).

Roman and Vasilescu (2016, p. 84) emphasise that the migration intentions among the Romanian teenagers are primarily based on personal accomplishment abroad, but, also important, influenced by paternal education and parental belonging to a certain social class [7] (p. 84).

Hypothesis 4 (H4). Individuals who are dissatisfied by bureaucracy, degraded work ethics, communist reminiscences and injustice in society, corruption, and the need for an illegitimate lobby for professional achievement, are more likely to leave the country of origin.

From another perspective, the willingness to migrate in other countries is determined by the subjective perceptions regarding the socioeconomic and political environment in the country of origin and, also, in the country of future residence [21,60]. "Corruption, excessive bureaucratisation, poor or inefficient organisation of public services, a lower endowment of infrastructures, lack of security, and an unsatisfactory social and cultural life may constitute a push factor for migration over and above conditions of income" [38] (p. 1631).

\section{Data and Methods}

During the university year 2017-2018, we have conducted a questionnaire-based investigation in three Romanian universities, namely Alexandru Ioan Cuza University of Iași (UAIC), Babes-Bolyai University of Cluj-Napoca (UBB), and Lucian Blaga University of Sibiu (ULBS). We have focused mainly on students in economics and business administration from the Faculty of Economics and Business Administration (FEAA, UAIC, Iasi), the Faculty of Economics and Business Administration (FSEGA, UBB, Cluj-Napoca), and from the Faculty of Economics (FSE, ULBS, Sibiu).

Given the socioeconomic nature of the phenomenon being analysed, the main criterion for constructing the sample was based on the idea of randomly including students enrolled in various economics modules, from both undergraduate and master programs of study, from at least three important Romanian universities, with students coming from different locations with various standard of living (Figure 1). For FEAA, the total considered population is of almost 7000 students, and we have collected a total number of 1100 unique responses for 1150 distributed questionnaires. For FSEGA, the total considered population is of almost 10,000 students, and we have collected 1564 unique responses from 1650 distributed questionnaires. For FSE, the total considered population is of almost 2400 students, and we have collected 387 unique responses from the 400 distributed. Therefore, the total amount of cases used involved 3051 distinct records. The percentage of complete responses exceeded 
$90 \%$. We have constructed the questionnaire based on our needs to explore the influence of personal motivations, beliefs, and attitudes on students' post-graduation migration intentions. Based on a solid literature review and having a clear operational definition for every concept or item, we were able to build proper open-ended and closed-ended questions, organised in specific sections. In this direction, to fully reduce confusion among the respondents, we kept them as simple as possible. In order to get a true opinion from the respondents regarding a certain item, and avoid the respondents' bias, we have used "cross-check" questions to determine the reliability of certain questions. The questionnaire was distributed in printed format, and completed face-to-face at the beginning or at the end of lectures and seminars or lab classes, due to the need for supervision and better control of the quality of responses. In order to guarantee the anonymity of the respondents, we did not collect any personal identification data, such as names or contact information.

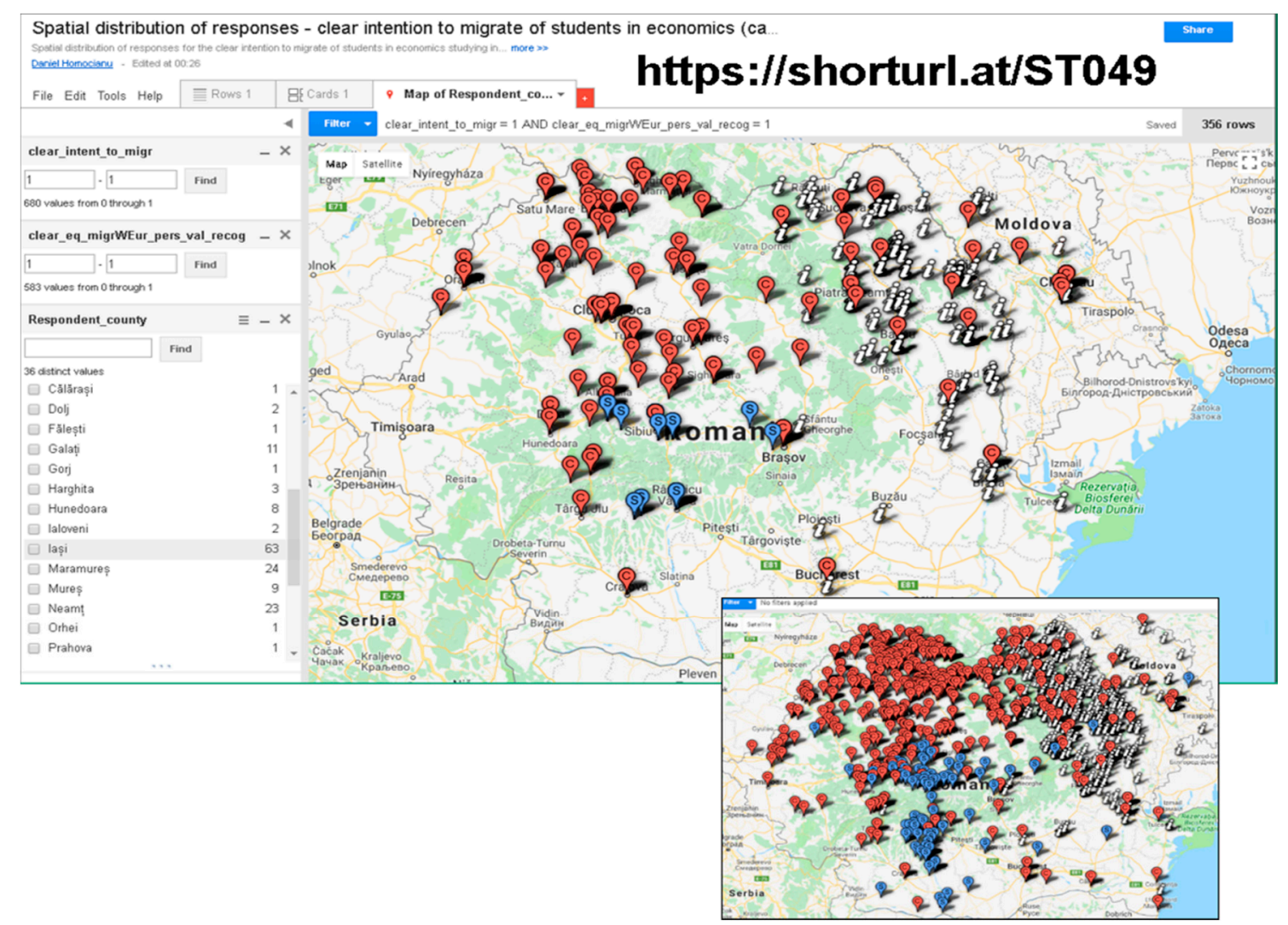

Figure 1. The spatial distribution of responses about the clear intention to migrate as interactive detailed map of coordinates with three iconographic symbols for the university centres the students belong to (2-FEAA, UAIC, Iasi, ?_FSEGA, UBB, Cluj-Napoca, ?_FSE, ULBS, Sibiu).

Taking into consideration the idea of robust research, based not just on offering support for replication of results, but also on triangulation [61], we have used many approaches, methods, and instruments to address the migration phenomenon and migration intentions.

Therefore, the raw data cleaning and processing involved the use of some spreadsheet functions responsible for treating fields having almost duplicate values (e.g., questions with an editable option); automatically constructing derived variables (e.g., dummy columns using IFs); checking exceptions generated by blank/not completed values for some fields (e.g., NULLs for average high school and baccalaureate grades_avg_HSG and $a v g_{-} \_B G$ ); and storing the final form of statistical reports with the appropriate symbols for all three levels of statistical significance used in most of the tables presented in this paper. 
In order to highlight the geographical distribution of responses, we have used an interactive queryable pushpin-based map of coordinates corresponding to respondents' residence, using the Google Fusion Tables experimental tool.

For identifying the baseline variable of our proposed models (the models' core) and its corresponding influence on the intention to migrate, we have created a general data mining model, starting from all 3051 responses and using a method based on Microsoft's neural network algorithm within two specialised tools: (1) a client application-the Data Mining add-in in Microsoft Excel or Excel DM, and (2) a server-side one-Microsoft SQL Server Analysis Services (SSAS), responsible for ensuring DM model's persistence and support for specific queries, namely of DMX type-Data Mining eXtensions to the traditional Structured Query Language (SQL).

In order to analyse the determinant factors that influence the probability to choose to migrate in Western Europe after graduation in our proposed models, we have started from a well-known generic econometric model, namely, the binary logistic regression model [62] (Equation (1)) as a particular case of multinomial logistic regression [63].

$$
\operatorname{Logit}(\mathrm{p})=\ln \left(\frac{\mathrm{p}}{1-\mathrm{p}}\right)=\beta_{0}+\beta_{1} * \text { clear_eq_migrWEur_pers_val_recog }+\sum_{\mathrm{j}=2}^{\mathrm{m}} \beta_{\mathrm{j}} * \mathrm{X}_{\mathrm{j}}+\varepsilon,
$$

where:

- $\quad \mathrm{p}$ is the probability of migrating in Western Europe after graduation;

- $(1-p)$ is the probability of not migrating in Western Europe after graduation;

- $\quad \mathrm{p} /(1-\mathrm{p})$ represents the odds of migrating in Western Europe after graduation;

- $j=2, \ldots, m$ and $m=$ the total number of independent variables;

- $\quad \beta_{\mathrm{j}}$ measures the effect of a change in variable $X_{\mathrm{j}}$ on the probability of migrating;

- clear_eq_migrWEur_pers_val_recog represents the core variable and it has the value of 1 only if the respondent clearly considers (excluding "I do not know") that the migration to Western Europe is equivalent to the recognition of his personal value, mostly a non-pecuniary variable;

- $\quad X_{j}$ is one explanatory variable (Equation (1)) from the array $(\Sigma)$ of the following family and individual characteristics (Table 1):

- $\quad$ respondent mother's ( $\left.m \_e d u\right)$ and father's education (d_edu) measured as number of school years (from 4 to 22 );

- $\quad$ severity level for the respondent's parents (parental_sev_lvl) measured on a 1 to 10 scale;

- $\quad$ a respondent coming from an urban location (urban), coded as 1 for Yes and 0 for No;

- $\quad$ income level of the family (income_lol), measured on a 1 to 7 scale, each value being associated to the following intervals: under $1500 \mathrm{RON}, 1500-2500, \ldots, 5500-6500$ and more than $6500 \mathrm{RON}$;

- $\quad$ respondent's number of siblings (no_of_sibl), measured on a 0 to 6 scale, where the values from 0 to 5 indicate the actual number of siblings and 6 indicates more than 5;

- $\quad$ respondent's parents gone abroad at least for one year (both_p_gone_abroad, only_m_gone_abroad, only_d_gone_abroad), all three coded as 1 for Yes and 0 for No;

- $\quad$ age of the respondent (age);

- $\quad$ respondent's presence of personality traits, namely, agreeableness (agreeable-evaluated as logical reunion of four options regarding the question concerning the values inherited from parents, namely, good manners, tolerance and respect for other people, obedience, and altruism), conscientiousness (consci-evaluated as logical reunion of three options regarding the same question, namely, hard work, responsibility, and perseverance) and openness (opn-evaluated as logical reunion of two options regarding the same question, namely, independence and creativity), all coded as 1 for Yes and 0 for No; 
- $\quad$ respondent's inclination to exact sciences (inclined_to_exact_sci), coded as 1 for Yes and 0 for No;

- $\quad$ individual beliefs and attitudes:

1. considerations regarding personal/internal religiosity (high_believe_in_God), coded as 1 for Yes (corresponding to the first two answer options, "very much so" and "quite a bit", for the following question "In which way do you believe in the existence of God or a divinity?"), and 0 for No (corresponding to the answer options: "Moderately", "Not very much" and "Not at all");

2. considerations about social religious behaviour/external religiosity (low frequency of church attendance-secular), coded as 1 for Yes (options: "Few times a year", "Less often" and "Never") and 0 for No (for the first two answer options: "More than once a week/Once a week" and "One to three times a month" of the question "How often do you participate to religious services?");

3. interpersonal trust level, measured on a 0 to 5 scale (interpers_trust_lvl);

4. considerations regarding economic and institutional issues as dummy variables: the private sector nature of a future career (priv), labour as source of success in life and society (lab_success_source), individual freedom as cause of progress (indiv_lib_clear_cause_of_progr), parental role in children's future (p_cl_asum_resp4child_future), attitude towards bribe (accept_or_doubts_about_bribe), and strong connections as the only way to succeed in career/accomplish a career in the native country (only_strong_conn4cl_acc_in);

5. four possible causes of migration, also coded as 1 for Yes and 0 for No: communist past (communist_past_migr_cause), injustice in society (injust_in_soc_migr_cause), corrupted/degraded work ethic (degrad_work_ethic_migr_cause), and excessive bureaucracy (excessive_bureaucracy_migr_cause);

- $\varepsilon$ represents the error term.

Additionally, we have tested our results obtained with the aforementioned model (Equation (1)) by using modified Poisson regressions [64] for binary data with robust error variance. The latter support interpretations focused directly on relative risks, and not on odds ratios treated as relative risks that, with the exception of rare phenomena, lead to undesirable exaggerations [65].

The entire statistical analysis based on binary logistic regressions, including post-estimation, was performed using the Stata 13.064 bits Multiprocessing/Parallel Edition software application.

The descriptive statistics, containing the list of all thirty variables (abbreviated format) originally considered for this study, are available in Table 1. More details and explanations about these variables are available in the text just below Equation (1). The three study sites (UAIC Iasi, UBB Cluj-Napoca, and ULBS Sibiu-Table 1) reveal, from the very beginning, noticeable differences in terms of clear intention to migrate (highest average for UAIC), presence of the psychological trait of openness (higher intensity for UBB and ULBS), secular behaviour (stronger evidence from ULBS), considering the communist past as a cause of migration (more obvious for UBB and ULBS), and strong connections as the only way to succeed in career in the native country (more intense for ULBS and UBB), belonging to urban area (weakest for UAIC), family income level (lowest for UAIC), number of siblings (higher values for UAIC and UBB), parental migration experience, especially that of the mother (lowest for UBB), and parental severity (lowest for UAIC). The differences between the estimated marginal means (EMM) and the descriptive statistics means (Table 1) indicate the mean residual for each variable of the thirty originally considered, which the regression equation does not take into account. Such residuals are easily noticeable as absolute values for the variables corresponding to the parents' education and severity ( $m \_e d u, d \_e d u$ and parental_sev_lvl) and the respondents' age, average baccalaureate grades, and interpersonal trust (age, $a v g \_B G$ and interpers_trust_lvl). They also indicate that some observations were lost, causing negligible imbalances in data. 
Table 1. Descriptive statistics for all university centres, including the abbreviations of all variables originally considered for the gradual introduction in regressions (three scenarios).

\begin{tabular}{|c|c|c|c|c|c|c|c|c|c|c|c|c|}
\hline \multirow{2}{*}{ Variables } & \multirow{2}{*}{ Obs. UAIC } & \multirow{2}{*}{$\begin{array}{c}\text { Mean } \\
\text { EMM (1036 Obs.) }\end{array}$} & \multirow{2}{*}{ Std. Dev. } & \multirow{2}{*}{$\begin{array}{l}\text { Min } \\
\text { Max }\end{array}$} & \multirow{2}{*}{ Obs. UBB } & \multirow{2}{*}{$\begin{array}{c}\text { Mean } \\
\text { EMM (1374 Obs.) }\end{array}$} & \multirow{2}{*}{ Std. Dev. } & \multirow{2}{*}{$\begin{array}{l}\text { Min } \\
\text { Max }\end{array}$} & \multirow{2}{*}{$\begin{array}{l}\text { Obs. } \\
\text { ULBS }\end{array}$} & \multirow{2}{*}{$\begin{array}{c}\text { Mean } \\
\text { EMM (343 Obs.) }\end{array}$} & \multirow{2}{*}{ Std. Dev. } & \multirow{2}{*}{$\begin{array}{l}\text { Min } \\
\text { Max }\end{array}$} \\
\hline & & & & & & & & & & & & \\
\hline clear_eq_migrWEur_pers_val_recog & 1100 & $\begin{array}{l}0.24 \\
0.24\end{array}$ & 0.43 & $\begin{array}{l}0 \\
1\end{array}$ & 1564 & $\begin{array}{l}0.21 \\
0.21\end{array}$ & 0.41 & $\begin{array}{l}0 \\
1\end{array}$ & 387 & $\begin{array}{l}0.23 \\
0.23\end{array}$ & 0.42 & $\begin{array}{l}0 \\
1\end{array}$ \\
\hline m_edu & 1100 & $\begin{array}{l}12.46 \\
12.48\end{array}$ & 2.63 & $\begin{array}{c}8 \\
22 \\
\end{array}$ & 1564 & $\begin{array}{c}13.3 \\
13.32 \\
\end{array}$ & 3.06 & $\begin{array}{c}4 \\
22 \\
\end{array}$ & 387 & $\begin{array}{l}12.47 \\
12.47\end{array}$ & 2.64 & $\begin{array}{c}8 \\
22 \\
\end{array}$ \\
\hline$d \_e d u$ & 1100 & $\begin{array}{l}12.21 \\
12.24\end{array}$ & 2.56 & $\begin{array}{c}8 \\
22\end{array}$ & 1564 & $\begin{array}{c}12.9 \\
12.91\end{array}$ & 2.93 & $\begin{array}{c}4 \\
22 \\
\end{array}$ & 387 & $\begin{array}{l}12.31 \\
12.27\end{array}$ & 2.54 & $\begin{array}{c}8 \\
22\end{array}$ \\
\hline parental_sev_lvl & 1100 & $\begin{array}{l}5.92 \\
5.96 \\
\end{array}$ & 2.33 & $\begin{array}{c}1 \\
10 \\
\end{array}$ & 1564 & $\begin{array}{l}6.24 \\
6.26 \\
\end{array}$ & 2.36 & $\begin{array}{c}0 \\
10 \\
\end{array}$ & 384 & $\begin{array}{c}6.63 \\
6.6 \\
\end{array}$ & 2.21 & $\begin{array}{c}1 \\
10 \\
\end{array}$ \\
\hline urban & 1100 & $\begin{array}{l}0.57 \\
0.58\end{array}$ & 0.49 & $\begin{array}{l}0 \\
1\end{array}$ & 1564 & $\begin{array}{l}0.75 \\
0.75\end{array}$ & 0.43 & $\begin{array}{l}0 \\
1\end{array}$ & 387 & $\begin{array}{l}0.67 \\
0.66\end{array}$ & 0.47 & $\begin{array}{l}0 \\
1\end{array}$ \\
\hline income_lvl & 1098 & $\begin{array}{l}2.84 \\
2.87\end{array}$ & 1.64 & $\begin{array}{l}1 \\
7\end{array}$ & 1519 & $\begin{array}{l}4.02 \\
4.03\end{array}$ & 1.88 & $\begin{array}{l}1 \\
7\end{array}$ & 381 & $\begin{array}{l}3.63 \\
3.65\end{array}$ & 1.69 & $\begin{array}{l}1 \\
7\end{array}$ \\
\hline no_of_sibl & 1100 & $\begin{array}{l}1.27 \\
1.27 \\
\end{array}$ & 1.11 & $\begin{array}{l}0 \\
6 \\
\end{array}$ & 1541 & $\begin{array}{l}1.03 \\
1.02 \\
\end{array}$ & 1.11 & $\begin{array}{l}0 \\
6 \\
\end{array}$ & 386 & $\begin{array}{l}0.94 \\
0.96 \\
\end{array}$ & 0.98 & $\begin{array}{l}0 \\
6 \\
\end{array}$ \\
\hline both_p_gone_abroad & 1100 & $\begin{array}{l}0.12 \\
0.12\end{array}$ & 0.33 & $\begin{array}{l}0 \\
1\end{array}$ & 1564 & $\begin{array}{l}0.12 \\
0.12\end{array}$ & 0.32 & $\begin{array}{l}0 \\
1\end{array}$ & 387 & $\begin{array}{c}0.1 \\
0.08\end{array}$ & 0.29 & $\begin{array}{l}0 \\
1\end{array}$ \\
\hline only_m_gone_abroad & 1100 & $\begin{array}{l}0.11 \\
0.11 \\
\end{array}$ & 0.31 & $\begin{array}{l}0 \\
1 \\
\end{array}$ & 1564 & $\begin{array}{l}0.05 \\
0.05 \\
\end{array}$ & 0.21 & $\begin{array}{l}0 \\
1 \\
\end{array}$ & 387 & $\begin{array}{l}0.1 \\
0.1 \\
\end{array}$ & 0.29 & $\begin{array}{l}0 \\
1 \\
\end{array}$ \\
\hline only_d_gone_abroad & 1100 & $\begin{array}{l}0.18 \\
0.18\end{array}$ & 0.39 & $\begin{array}{l}0 \\
1\end{array}$ & 1564 & $\begin{array}{l}0.17 \\
0.17\end{array}$ & 0.38 & $\begin{array}{l}0 \\
1\end{array}$ & 387 & $\begin{array}{l}0.17 \\
0.18\end{array}$ & 0.37 & $\begin{array}{l}0 \\
1\end{array}$ \\
\hline age & 1100 & $\begin{array}{l}20.67 \\
20.64\end{array}$ & 3.06 & $\begin{array}{l}18 \\
47\end{array}$ & 1522 & $\begin{array}{l}20.68 \\
20.67\end{array}$ & 2.4 & $\begin{array}{l}18 \\
48\end{array}$ & 374 & $\begin{array}{l}20.81 \\
20.79\end{array}$ & 1.29 & $\begin{array}{l}18 \\
30\end{array}$ \\
\hline agreeable & 1100 & $\begin{array}{l}0.95 \\
0.94 \\
\end{array}$ & 0.23 & $\begin{array}{l}0 \\
1 \\
\end{array}$ & 1564 & $\begin{array}{l}0.94 \\
0.95 \\
\end{array}$ & 0.24 & $\begin{array}{l}0 \\
1 \\
\end{array}$ & 387 & $\begin{array}{l}0.97 \\
0.98\end{array}$ & 0.18 & $\begin{array}{l}0 \\
1 \\
\end{array}$ \\
\hline consci & 1100 & $\begin{array}{l}0.92 \\
0.92\end{array}$ & 0.26 & $\begin{array}{l}0 \\
1\end{array}$ & 1564 & $\begin{array}{l}0.92 \\
0.93\end{array}$ & 0.27 & $\begin{array}{l}0 \\
1\end{array}$ & 387 & $\begin{array}{l}0.96 \\
0.97\end{array}$ & 0.21 & $\begin{array}{l}0 \\
1\end{array}$ \\
\hline opn & 1100 & $\begin{array}{l}0.6 \\
0.6\end{array}$ & 0.49 & $\begin{array}{l}0 \\
1\end{array}$ & 1564 & $\begin{array}{l}0.72 \\
0.73\end{array}$ & 0.45 & $\begin{array}{l}0 \\
1\end{array}$ & 387 & $\begin{array}{l}0.76 \\
0.78\end{array}$ & 0.43 & $\begin{array}{l}0 \\
1\end{array}$ \\
\hline inclined_to_exact_sci & 1100 & $\begin{array}{l}0.65 \\
0.66\end{array}$ & 0.48 & $\begin{array}{l}0 \\
1 \\
\end{array}$ & 1564 & $\begin{array}{l}0.66 \\
0.67\end{array}$ & 0.47 & $\begin{array}{l}0 \\
1 \\
\end{array}$ & 387 & $\begin{array}{l}0.56 \\
0.57\end{array}$ & 0.5 & $\begin{array}{l}0 \\
1 \\
\end{array}$ \\
\hline avg_HSG & 1041 & $\begin{array}{l}8.91 \\
8.91 \\
\end{array}$ & 0.66 & $\begin{array}{c}5.23 \\
10\end{array}$ & 1461 & $\begin{array}{l}9.07 \\
9.08\end{array}$ & 0.63 & $\begin{array}{l}5.1 \\
10\end{array}$ & 362 & $\begin{array}{l}8.69 \\
8.68 \\
\end{array}$ & 0.68 & $\begin{array}{c}6 \\
10\end{array}$ \\
\hline$a v g_{-} B G$ & 1084 & $\begin{array}{l}8.27 \\
8.28\end{array}$ & 0.88 & $\begin{array}{c}6 \\
10\end{array}$ & 1516 & $\begin{array}{l}8.56 \\
8.58\end{array}$ & 0.87 & $\begin{array}{l}5.5 \\
10\end{array}$ & 375 & $\begin{array}{l}8.14 \\
8.16\end{array}$ & 0.9 & $\begin{array}{c}6 \\
10\end{array}$ \\
\hline
\end{tabular}


Table 1. Cont

\begin{tabular}{|c|c|c|c|c|c|c|c|c|c|c|c|c|}
\hline \multirow{2}{*}{ Variables } & \multirow{2}{*}{ Obs. UAIC } & \multirow{2}{*}{$\begin{array}{c}\text { Mean } \\
\text { EMM (1036 Obs.) } \\
\end{array}$} & \multirow{2}{*}{ Std. Dev. } & \multirow{2}{*}{$\begin{array}{l}\text { Min } \\
\text { Max }\end{array}$} & \multirow{2}{*}{ Obs. UBB } & \multirow{2}{*}{$\begin{array}{c}\text { Mean } \\
\text { EMM (1374 Obs.) }\end{array}$} & \multirow{2}{*}{ Std. Dev. } & \multirow{2}{*}{$\begin{array}{l}\text { Min } \\
\text { Max }\end{array}$} & \multirow{2}{*}{$\begin{array}{l}\text { Obs. } \\
\text { ULBS }\end{array}$} & \multirow{2}{*}{$\begin{array}{c}\text { Mean } \\
\text { EMM (343 Obs.) }\end{array}$} & \multirow{2}{*}{ Std. Dev. } & \multirow{2}{*}{$\begin{array}{l}\text { Min } \\
\text { Max }\end{array}$} \\
\hline & & & & & & & & & & & & \\
\hline high_believe_in_God & 1100 & $\begin{array}{l}0.77 \\
0.77\end{array}$ & 0.42 & $\begin{array}{l}0 \\
1\end{array}$ & 1564 & $\begin{array}{c}0.7 \\
0.71\end{array}$ & 0.46 & $\begin{array}{l}0 \\
1\end{array}$ & 387 & $\begin{array}{l}0.76 \\
0.78\end{array}$ & 0.43 & $\begin{array}{l}0 \\
1\end{array}$ \\
\hline secular & 1100 & $\begin{array}{l}0.62 \\
0.62\end{array}$ & 0.49 & $\begin{array}{l}0 \\
1\end{array}$ & 1564 & $\begin{array}{l}0.62 \\
0.64\end{array}$ & 0.49 & $\begin{array}{l}0 \\
1\end{array}$ & 387 & $\begin{array}{l}0.78 \\
0.78\end{array}$ & 0.42 & $\begin{array}{l}0 \\
1\end{array}$ \\
\hline interpers_trust_lol & 1100 & $\begin{array}{r}2.4 \\
2.41\end{array}$ & 0.87 & $\begin{array}{l}0 \\
5\end{array}$ & 1564 & $\begin{array}{l}2.53 \\
2.55 \\
\end{array}$ & 0.99 & $\begin{array}{l}0 \\
5 \\
\end{array}$ & 387 & $\begin{array}{l}2.41 \\
2.43 \\
\end{array}$ & 1.04 & $\begin{array}{l}0 \\
5 \\
\end{array}$ \\
\hline priv & 1100 & $\begin{array}{l}0.81 \\
0.82 \\
\end{array}$ & 0.39 & $\begin{array}{l}0 \\
1\end{array}$ & 1564 & $\begin{array}{l}0.87 \\
0.88\end{array}$ & 0.33 & $\begin{array}{l}0 \\
1\end{array}$ & 386 & $\begin{array}{l}0.82 \\
0.83\end{array}$ & 0.38 & $\begin{array}{l}0 \\
1 \\
\end{array}$ \\
\hline lab_success_source & 1100 & $\begin{array}{l}0.95 \\
0.95 \\
\end{array}$ & 0.22 & $\begin{array}{l}0 \\
1 \\
\end{array}$ & 1564 & $\begin{array}{l}0.91 \\
0.91 \\
\end{array}$ & 0.29 & $\begin{array}{l}0 \\
1 \\
\end{array}$ & 387 & $\begin{array}{l}0.93 \\
0.94 \\
\end{array}$ & 0.26 & $\begin{array}{l}0 \\
1 \\
\end{array}$ \\
\hline indiv_lib_clear_cause_of_progr & 1100 & $\begin{array}{l}0.71 \\
0.72 \\
\end{array}$ & 0.45 & $\begin{array}{l}0 \\
1\end{array}$ & 1564 & $\begin{array}{l}0.74 \\
0.75 \\
\end{array}$ & 0.44 & $\begin{array}{l}0 \\
1\end{array}$ & 387 & $\begin{array}{l}0.68 \\
0.69\end{array}$ & 0.47 & $\begin{array}{l}0 \\
1 \\
\end{array}$ \\
\hline accept_or_doubts_about_bribe & 1100 & $\begin{array}{l}0.11 \\
0.11\end{array}$ & 0.31 & $\begin{array}{l}0 \\
1\end{array}$ & 1564 & $\begin{array}{l}0.12 \\
0.12\end{array}$ & 0.32 & $\begin{array}{l}0 \\
1\end{array}$ & 387 & $\begin{array}{l}0.12 \\
0.11\end{array}$ & 0.33 & $\begin{array}{l}0 \\
1\end{array}$ \\
\hline p_cl_asum_resp4child_future & 1100 & $\begin{array}{l}0.88 \\
0.88\end{array}$ & 0.32 & $\begin{array}{l}0 \\
1\end{array}$ & 1564 & $\begin{array}{l}0.84 \\
0.85\end{array}$ & 0.36 & $\begin{array}{l}0 \\
1\end{array}$ & 387 & $\begin{array}{l}0.91 \\
0.91\end{array}$ & 0.29 & $\begin{array}{l}0 \\
1\end{array}$ \\
\hline only_strong_conn 4 cl_acc_in & 1100 & $\begin{array}{c}0.3 \\
0.29 \\
\end{array}$ & 0.46 & $\begin{array}{l}0 \\
1\end{array}$ & 1564 & $\begin{array}{l}0.33 \\
0.32 \\
\end{array}$ & 0.47 & $\begin{array}{l}0 \\
1\end{array}$ & 387 & $\begin{array}{l}0.37 \\
0.36 \\
\end{array}$ & 0.48 & $\begin{array}{l}0 \\
1 \\
\end{array}$ \\
\hline communist_past_migr_cause & 1100 & $\begin{array}{l}0.36 \\
0.37\end{array}$ & 0.48 & $\begin{array}{l}0 \\
1\end{array}$ & 1564 & $\begin{array}{l}0.46 \\
0.47\end{array}$ & 0.5 & $\begin{array}{l}0 \\
1\end{array}$ & 387 & $\begin{array}{l}0.44 \\
0.45\end{array}$ & 0.5 & $\begin{array}{l}0 \\
1\end{array}$ \\
\hline injust_in_soc_migr_cause & 1100 & $\begin{array}{l}0.24 \\
0.25\end{array}$ & 0.43 & $\begin{array}{l}0 \\
1\end{array}$ & 1564 & $\begin{array}{l}0.44 \\
0.45\end{array}$ & 0.5 & $\begin{array}{l}0 \\
1\end{array}$ & 387 & $\begin{array}{l}0.47 \\
0.49\end{array}$ & 0.5 & 0 \\
\hline degrad_work_ethic_migr_cause & 1100 & $\begin{array}{l}0.15 \\
0.15 \\
\end{array}$ & 0.36 & $\begin{array}{l}0 \\
1\end{array}$ & 1564 & $\begin{array}{l}0.24 \\
0.25 \\
\end{array}$ & 0.43 & $\begin{array}{l}0 \\
1\end{array}$ & 387 & $\begin{array}{l}0.25 \\
0.27\end{array}$ & 0.43 & $\begin{array}{l}0 \\
1 \\
\end{array}$ \\
\hline excessive_bureaucracy_migr_cause & 1100 & $\begin{array}{l}0.31 \\
0.32 \\
\end{array}$ & 0.46 & $\begin{array}{l}0 \\
1 \\
\end{array}$ & 1564 & $\begin{array}{c}0.4 \\
0.41 \\
\end{array}$ & 0.49 & $\begin{array}{l}0 \\
1 \\
\end{array}$ & 387 & $\begin{array}{l}0.42 \\
0.43 \\
\end{array}$ & 0.49 & $\begin{array}{l}0 \\
1 \\
\end{array}$ \\
\hline clear_intent_to_migr (Outcome) & 1100 & $\begin{array}{c}0.24 \\
-\end{array}$ & 0.43 & $\begin{array}{l}0 \\
1\end{array}$ & 1564 & 0.17 & 0.38 & $\begin{array}{l}0 \\
1\end{array}$ & 387 & $\begin{array}{c}0.13 \\
-\end{array}$ & 0.34 & $\begin{array}{l}0 \\
1\end{array}$ \\
\hline
\end{tabular}

Source: Own calculations in Stata 13. Note: EMM stands for estimated marginal means that were computed for those thirty variables initially considered, and the three different regional subsets corresponding to the study sites using the "margins" post-estimation command. 


\section{Results and Discussions}

This section presents the results after georeferencing and mining the data and, also, after performing both binary logistic and modified Poisson regressions for all regions and, separately, with statistical results useful for testing the validity of the initial hypotheses. Moreover, an in-depth perspective is provided by taking into consideration all significant influences for a large set of variables. The results highlight, for the entire sample and each historical region, the main combined influences that are responsible for students' post-graduation intentions to migrate abroad.

First of all, it is interesting to note the percentages of students in economics that express their clear intentions to leave the country of origin: $24 \%$ from those who study in Iași, $17 \%$ from Cluj-Napoca, and $13 \%$ from Sibiu. In addition, our results reveal an overall probability of obvious migration intentions of approximately $19 \%$, as a weighted average of the mean values of the outcome for all three university centres (Table 1).

The geographical distribution of responses as an interactive queryable pushpin map of coordinates in Fusion Tables (Figure 1), of clear intention to migrate of students from all three university centres, was made starting from all records of the questionnaire (Rows 1 button-Figure 1). The precise coordinates of the respondents' residence were automatically extracted using a Google Maps API (application programming interface) and a powerful function, namely IMPORTXML from Google Sheets, e.g., =IMPORTXML("http://maps.googleapis.com/maps/api/geocode/xml?address=" EC2," / GeocodeResponse//location"). The referenced cells (all 3051 starting from C2) were used to store the full respondents' residence (e.g., "Focșani, Vrancea, Romania" as city/town/village, county/district and country). No API key was required when extracting these coordinates (July 2018).

This map of coordinates shows the respondents' precise locations of origin, which cover a large portion of Romania and also places from Moldova (part of the former Romanian territory), and provides many filter possibilities corresponding to all variables originally considered for this study.

In order to compute the average clear intention to migrate in Romanian counties of origin (97.31\%—only Romanian students), we have started from synthetic data after pre-filtering on such counties. Then, we have created a pivot table with average values for this intention and count-based ones for the number of responses in each of all these counties. The resulting average clear intention to migrate in Romanian counties of origin ranged between 0 and 0.6 . More, this secondary synthetic dataset may serve as a support for a new queryable map (heat map on counties of origin), if necessary.

The general DM model (Figure 2) highlights the powerful effect of a variable associated with the question "Migrating to Western Europe equals for you with the recognition of your personal value? Yes/No/I do not know", from which we retained (variable clear_eq_migrWEur_pers_val_recog) only the clear conviction regarding this equivalence ("Yes" coded as 1, "No" and "I do not know" as 0). This variable's overwhelming influence, explainable by admitting the holistic nature of the corresponding question above, is also proven by a study on the migration enablers of Romanian students in theology [66] based on four hundred distinct responses. This strong influence is in line with an explanation offered by neoclassical macroeconomics, and mentioned in the review of Massey et al. (1993), by successfully confirming the differences between the migration patterns of skilled workers compared to those of unqualified ones [67].

We have performed multicollinearity consecutive tests starting from all thirty variables (Table 1) originally considered in our entire dataset (all 3051 responses). We only accepted corresponding VIF (variance inflation factor) values below 5 and, additionally, an average less than 2.5 , while a worrying collinearity is usually considered for VIF $>10$ [68]. Consequently, we have dropped twelve variables with high intercorrelation, and responsible for causing inflated estimations and inaccurate variances [69] (p. 1). After eliminating these problematic variables in a specific order (avg_HSG, avg_BG, age, d_edu, m_edu, agreeable, consci, lab_success_source, parental_sev_lvl, interpers_trust_lvl, p_cl_asum_resp4child_future, priv), no signs of multicollinearity have been detected, and this is proof of a reliable binary logistic regression. Moreover, this cleaned set of variables also increased the percentage of complete records (at least 95\%). Tables 2-4 correspond to three regional models 
developed considering the answers in each of the three university centres from Iasi, Cluj-Napoca, and Sibiu.

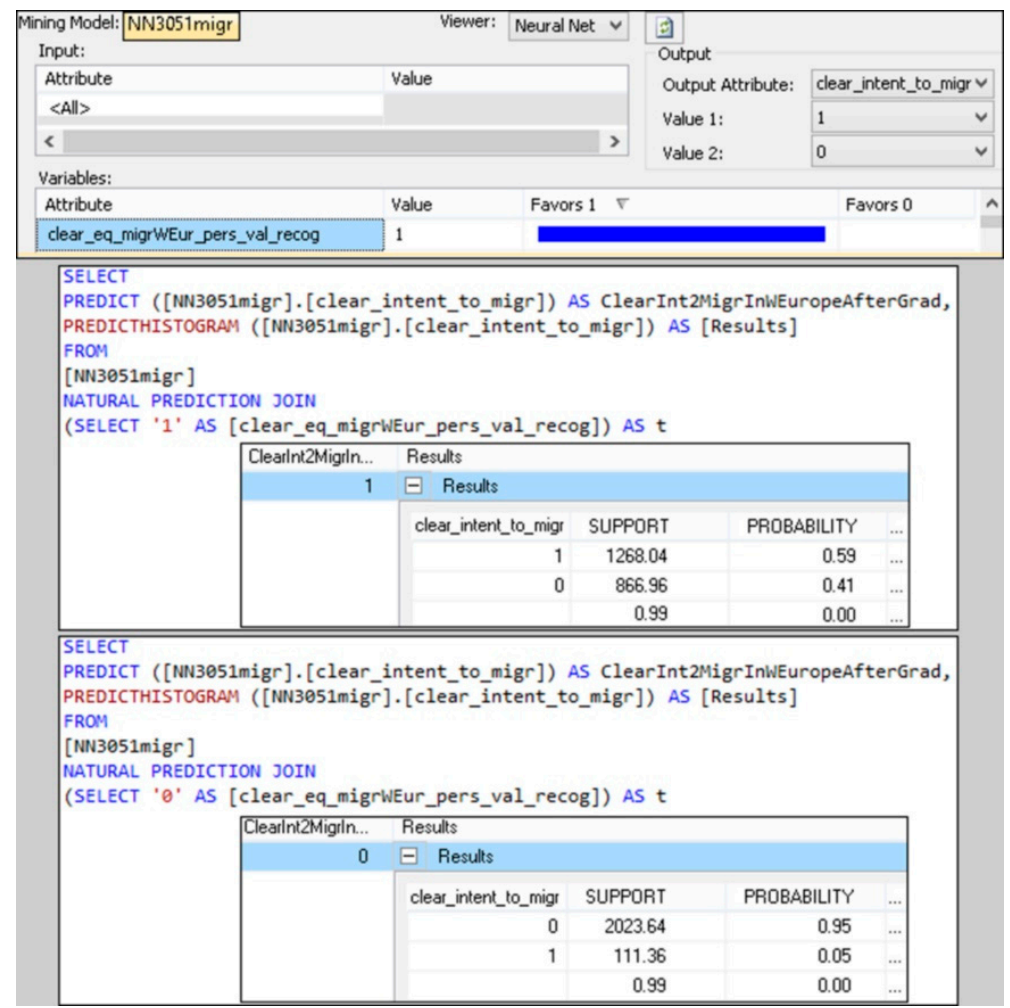

Figure 2. The core (top influence) of the general model as result of using data mining tools: neural networks-based algorithm in Microsoft Excel DM and DMX queries in Microsoft SSAS.

Table 2. Raw coefficients (Logit vs. Poisson) of the model based on responses from FEAA, UAIC (Iasi).

\begin{tabular}{|c|c|c|c|c|c|c|}
\hline \multirow{2}{*}{ Variables } & \multicolumn{3}{|c|}{ Logit Regression } & \multicolumn{3}{|c|}{ Poisson Regression with Robust Standard Errors } \\
\hline & (a) & (b) & (c) & (d) & (e) & (f) \\
\hline clear_eq_migrWEur_pers_val_recog & $\begin{array}{c}2.245^{* * *} \\
(0.162)\end{array}$ & $\begin{array}{c}2.239^{* * *} \\
(0.163)\end{array}$ & $\begin{array}{c}2.232 * * * \\
(0.169)\end{array}$ & $\begin{array}{c}1.499^{* * *} \\
(0.103)\end{array}$ & $\begin{array}{c}1.493^{* * *} \\
(0.104)\end{array}$ & $\begin{array}{c}1.446^{* * *} \\
(0.106)\end{array}$ \\
\hline urban & & $\begin{array}{l}-0.101 \\
(0.167)\end{array}$ & $\begin{array}{c}-0.156 \\
(0.171)\end{array}$ & & $\begin{array}{c}-0.0616 \\
(0.100)\end{array}$ & $\begin{array}{c}-0.0991 \\
(0.100)\end{array}$ \\
\hline income_lvl & & $\begin{array}{c}-0.0092 \\
(0.051)\end{array}$ & $\begin{array}{c}-0.0346 \\
(0.052)\end{array}$ & & $\begin{array}{c}-0.00574 \\
(0.033)\end{array}$ & $\begin{array}{c}-0.0208 \\
(0.032)\end{array}$ \\
\hline no_of_sibl & & $\begin{array}{c}-0.0506 \\
(0.077)\end{array}$ & $\begin{array}{c}-0.0172 \\
(0.077)\end{array}$ & & $\begin{array}{c}-0.0327 \\
(0.047)\end{array}$ & $\begin{array}{c}-0.0113 \\
(0.046)\end{array}$ \\
\hline both_p_gone_abroad & & $\begin{array}{c}0.103 \\
(0.242) \\
\end{array}$ & $\begin{array}{c}0.182 \\
(0.242) \\
\end{array}$ & & $\begin{array}{l}0.0587 \\
(0.147)\end{array}$ & $\begin{array}{c}0.138 \\
(0.150) \\
\end{array}$ \\
\hline only_m_gone_abroad & & $\begin{array}{l}-0.079 \\
(0.262) \\
\end{array}$ & $\begin{array}{c}-0.0756 \\
(0.267)\end{array}$ & & $\begin{array}{c}-0.0445 \\
(0.157)\end{array}$ & $\begin{array}{l}-0.028 \\
(0.156)\end{array}$ \\
\hline only_d_gone_abroad & & $\begin{array}{c}0.00939 \\
(0.212)\end{array}$ & $\begin{array}{l}0.0705 \\
(0.219) \\
\end{array}$ & & $\begin{array}{c}0.00672 \\
(0.122) \\
\end{array}$ & $\begin{array}{l}0.0368 \\
(0.124)\end{array}$ \\
\hline opn & & & $\begin{array}{c}-0.18 \\
(0.167)\end{array}$ & & & $\begin{array}{l}-0.106 \\
(0.098)\end{array}$ \\
\hline inclined_to_exact_sci & & & $\begin{array}{c}-0.216 \\
(0.167)\end{array}$ & & & $\begin{array}{c}-0.13 \\
(0.101)\end{array}$ \\
\hline high_believe_in_God & & & $\begin{array}{l}-0.231 \\
(0.201)\end{array}$ & & & $\begin{array}{l}-0.126 \\
(0.120)\end{array}$ \\
\hline
\end{tabular}


Table 2. Cont.

\begin{tabular}{|c|c|c|c|c|c|c|}
\hline \multirow{2}{*}{ Variables } & \multicolumn{3}{|c|}{ Logit Regression } & \multicolumn{3}{|c|}{ Poisson Regression with Robust Standard Errors } \\
\hline & (a) & (b) & (c) & (d) & (e) & (f) \\
\hline secular & & & $\begin{array}{c}0.521^{* * *} \\
(0.187)\end{array}$ & & & $\begin{array}{c}0.321^{* * *} \\
(0.115)\end{array}$ \\
\hline indiv_lib_clear_cause_of_progr & & & $\begin{array}{c}0.428 * * \\
(0.191)\end{array}$ & & & $\begin{array}{c}0.273^{* *} \\
(0.122)\end{array}$ \\
\hline accept_or_doubts_about_bribe & & & $\begin{array}{l}0.0696 \\
(0.256)\end{array}$ & & & $\begin{array}{l}0.0389 \\
(0.146)\end{array}$ \\
\hline only_strong_conn $4 c l \_a c c \_i n$ & & & $\begin{array}{c}0.116 \\
(0.175)\end{array}$ & & & $\begin{array}{l}0.0535 \\
(0.100)\end{array}$ \\
\hline communist_past_migr_cause & & & $\begin{array}{c}0.155 \\
(0.169)\end{array}$ & & & $\begin{array}{l}0.0914 \\
(0.102)\end{array}$ \\
\hline injust_in_soc_migr_cause & & & $\begin{array}{c}0.16 \\
(0.193)\end{array}$ & & & $\begin{array}{l}0.0855 \\
(0.110)\end{array}$ \\
\hline degrad_work_ethic_migr_cause & & & $\begin{array}{c}0.254 \\
(0.223)\end{array}$ & & & $\begin{array}{c}0.158 \\
(0.130)\end{array}$ \\
\hline excesive_bureaucracy_migr_cause & & & $\begin{array}{c}0.111 \\
(0.182)\end{array}$ & & & $\begin{array}{l}0.0677 \\
(0.110)\end{array}$ \\
\hline CONSTANT & $\begin{array}{c}-1.890 \\
* * * \\
(0.102)\end{array}$ & $\begin{array}{c}-1.746 \\
* * * \\
(0.229)\end{array}$ & $\begin{array}{c}-2.161 \\
* * * \\
(0.403)\end{array}$ & $\begin{array}{c}-2.031 * * * \\
(0.089)\end{array}$ & $\begin{array}{c}-1.939 * * * \\
(0.157)\end{array}$ & $\begin{array}{c}-2.207^{* * *} \\
(0.273)\end{array}$ \\
\hline Observations & 1100 & 1098 & 1098 & 1100 & 1098 & 1098 \\
\hline LR chi2 (df) | Wald chi2(df) & 205.68 & 206.25 & 232.34 & 212.34 & 214.97 & 274.93 \\
\hline$d f$ & 1 & 7 & 18 & 1 & 7 & 18 \\
\hline Prob $>$ chi2 & 0.0000 & 0.0000 & 0.0000 & 0.0000 & 0.0000 & 0.0000 \\
\hline Pseudo R square & 0.1697 & 0.1703 & 0.1918 & 0.1117 & 0.112 & 0.1244 \\
\hline$A U C(R O C)$ & 0.7271 & 0.7356 & 0.7816 & $\mathrm{~N} / \mathrm{A}$ & $\mathrm{N} / \mathrm{A}$ & $\mathrm{N} / \mathrm{A}$ \\
\hline
\end{tabular}

Source: Own calculations for all specifications/scenarios progressively, including the core variable-scenario (a)/(d) and the background controls—scenarios (b) and (c)/(e) and (f). Note: Standard errors in parentheses. ${ }^{*}, * *$, *** indicate significance at $10 \%, 5 \%$, and $1 \%$, respectively.

Table 3. Raw coefficients (Logit vs. Poisson) of the model based on responses from FSEGA, UBB (Cluj-Napoca).

\begin{tabular}{|c|c|c|c|c|c|c|}
\hline \multirow{2}{*}{ Variables } & \multicolumn{3}{|c|}{ Logit Regression } & \multicolumn{3}{|c|}{ Poisson Regression with Robust Standard Errors } \\
\hline & (a) & (b) & (c) & (d) & (e) & (f) \\
\hline clear_eq_migrWEur_pers_val_recog & $\begin{array}{c}2.495^{* * *} \\
(0.152)\end{array}$ & $\begin{array}{c}2.433^{* * *} \\
(0.157)\end{array}$ & $\begin{array}{c}2.381 * * * \\
(0.162)\end{array}$ & $\begin{array}{c}1.858^{* * *} \\
(0.110)\end{array}$ & $\begin{array}{c}1.798^{* * *} \\
(0.116)\end{array}$ & $\begin{array}{c}1.717^{* * *} \\
(0.120)\end{array}$ \\
\hline urban & & $\begin{array}{l}0.0917 \\
(0.190) \\
\end{array}$ & $\begin{array}{l}0.0753 \\
(0.194) \\
\end{array}$ & & $\begin{array}{l}0.0664 \\
(0.129) \\
\end{array}$ & $\begin{array}{l}0.0451 \\
(0.131) \\
\end{array}$ \\
\hline income_lvl & & $\begin{array}{c}-0.0196 \\
(0.042)\end{array}$ & $\begin{array}{c}-0.0448 \\
(0.044)\end{array}$ & & $\begin{array}{l}-0.012 \\
(0.027)\end{array}$ & $\begin{array}{c}-0.0311 \\
(0.028)\end{array}$ \\
\hline no_of_sibl & & $\begin{array}{l}-0.103 \\
(0.074)\end{array}$ & $\begin{array}{c}-0.131 * \\
(0.077)\end{array}$ & & $\begin{array}{c}-0.0677 \\
(0.045)\end{array}$ & $\begin{array}{c}-0.0881 * \\
(0.045)\end{array}$ \\
\hline both_p_gone_abroad & & $\begin{array}{c}0.633^{* * *} \\
(0.224)\end{array}$ & $\begin{array}{c}0.688^{* * *} \\
(0.230)\end{array}$ & & $\begin{array}{c}0.391 * * * \\
(0.140)\end{array}$ & $\begin{array}{c}0.403^{* * *} \\
(0.138)\end{array}$ \\
\hline only_m_gone_abroad & & $\begin{array}{l}0.603 * \\
(0.319)\end{array}$ & $\begin{array}{l}0.591 * \\
(0.325)\end{array}$ & & $\begin{array}{l}0.363^{*} \\
(0.189)\end{array}$ & $\begin{array}{l}0.347^{*} \\
(0.196)\end{array}$ \\
\hline only_d_gone_abroad & & $\begin{array}{c}0.21 \\
(0.211)\end{array}$ & $\begin{array}{c}0.208 \\
(0.215)\end{array}$ & & $\begin{array}{c}0.141 \\
(0.139)\end{array}$ & $\begin{array}{c}0.129 \\
(0.137)\end{array}$ \\
\hline opn & & & $\begin{array}{c}0.141 \\
(0.186)\end{array}$ & & & $\begin{array}{l}0.0905 \\
(0.127)\end{array}$ \\
\hline inclined_to_exact_sci & & & $\begin{array}{c}0.23 \\
(0.170)\end{array}$ & & & $\begin{array}{c}0.147 \\
(0.107)\end{array}$ \\
\hline high_believe_in_God & & & $\begin{array}{c}-0.515^{* * *} \\
(0.182)\end{array}$ & & & $\begin{array}{c}-0.316^{* * *} \\
(0.118)\end{array}$ \\
\hline secular & & & $\begin{array}{c}-0.308 * \\
(0.181)\end{array}$ & & & $\begin{array}{l}-0.208 * \\
(0.121)\end{array}$ \\
\hline
\end{tabular}


Table 3. Cont.

\begin{tabular}{|c|c|c|c|c|c|c|}
\hline \multirow{2}{*}{ Variables } & \multicolumn{3}{|c|}{ Logit Regression } & \multicolumn{3}{|c|}{ Poisson Regression with Robust Standard Errors } \\
\hline & (a) & (b) & (c) & (d) & (e) & (f) \\
\hline indiv_lib_clear_cause_of_progr & & & $\begin{array}{c}0.504^{* *} \\
(0.205)\end{array}$ & & & $\begin{array}{c}0.333^{* *} \\
(0.141)\end{array}$ \\
\hline accept_or_doubts_about_bribe & & & $\begin{array}{l}-0.161 \\
(0.249)\end{array}$ & & & $\begin{array}{c}-0.0911 \\
(0.175)\end{array}$ \\
\hline only_strong_conn4cl_acc_in & & & $\begin{array}{c}0.334^{* *} \\
(0.165)\end{array}$ & & & $\begin{array}{l}0.222 * * \\
(0.103)\end{array}$ \\
\hline communist_past_migr_cause & & & $\begin{array}{c}0.229 \\
(0.165)\end{array}$ & & & $\begin{array}{c}0.145 \\
(0.104)\end{array}$ \\
\hline injust_in_soc_migr_cause & & & $\begin{array}{c}-0.0126 \\
(0.167)\end{array}$ & & & $\begin{array}{c}0.00607 \\
(0.106)\end{array}$ \\
\hline degrad_work_ethic_migr_cause & & & $\begin{array}{l}-0.278 \\
(0.194)\end{array}$ & & & $\begin{array}{l}-0.179 \\
(0.127)\end{array}$ \\
\hline excesive_bureaucracy_migr_cause & & & $\begin{array}{c}0.263 \\
(0.170)\end{array}$ & & & $\begin{array}{c}0.168 \\
(0.110)\end{array}$ \\
\hline CONSTANT & $\begin{array}{c}-2.440^{* * *} \\
(0.105)\end{array}$ & $\begin{array}{c}-2.465^{* * *} \\
(0.258)\end{array}$ & $\begin{array}{c}-2.683^{* * *} \\
(0.405)\end{array}$ & $\begin{array}{c}-2.524^{* * *} \\
(0.096)\end{array}$ & $\begin{array}{c}-2.536^{* * *} \\
(0.187)\end{array}$ & $\begin{array}{c}-2.657^{* * *} \\
(0.267)\end{array}$ \\
\hline Observations & 1564 & 1501 & 1501 & 1564 & 1501 & 1501 \\
\hline LR chi2(df)| Wald chi2(df) & 287.33 & 282.8 & 310.91 & 283.37 & 313.58 & 394.49 \\
\hline$d f$ & 1 & 7 & 18 & 1 & 7 & 18 \\
\hline Prob $>$ chi2 & 0.0000 & 0.0000 & 0.0000 & 0.0000 & 0.0000 & 0.0000 \\
\hline Pseudo R square & 0.2006 & 0.2058 & 0.2262 & 0.1489 & 0.1517 & 0.1645 \\
\hline$A U C(R O C)$ & 0.7536 & 0.7863 & 0.8073 & $\mathrm{~N} / \mathrm{A}$ & $\mathrm{N} / \mathrm{A}$ & $\mathrm{N} / \mathrm{A}$ \\
\hline
\end{tabular}

Source and Note are the same as in Table 2.

Table 4. Raw coefficients (Logit vs. Poisson) of the model based on responses from FSE, ULBS (Sibiu).

\begin{tabular}{|c|c|c|c|c|c|c|}
\hline \multirow{2}{*}{ Variables } & \multicolumn{3}{|c|}{ Logit Regression } & \multicolumn{3}{|c|}{ Poisson Regression with Robust Standard Errors } \\
\hline & (a) & (b) & (c) & (d) & (e) & (f) \\
\hline clear_eq_migrWEur_pers_val_recog & $\begin{array}{c}2.216^{* * *} \\
(0.328)\end{array}$ & $\begin{array}{c}2.320^{* * *} \\
(0.340)\end{array}$ & $\begin{array}{c}2.169 * * * \\
(0.374)\end{array}$ & $\begin{array}{c}1.815^{* * *} \\
(0.267)\end{array}$ & $\begin{array}{c}1.864^{* * *} \\
(0.264)\end{array}$ & $\begin{array}{c}1.555^{* * *} \\
(0.272)\end{array}$ \\
\hline Urban & & $\begin{array}{c}0.438 \\
(0.372)\end{array}$ & $\begin{array}{c}0.32 \\
(0.403)\end{array}$ & & $\begin{array}{c}0.318 \\
(0.275)\end{array}$ & $\begin{array}{c}0.173 \\
(0.270)\end{array}$ \\
\hline income_lvl & & $\begin{array}{c}-0.0998 \\
(0.100)\end{array}$ & $\begin{array}{c}-0.18 \\
(0.110)\end{array}$ & & $\begin{array}{c}-0.0717 \\
(0.069)\end{array}$ & $\begin{array}{l}-0.122 \\
(0.075)\end{array}$ \\
\hline no_of_sibl & & $\begin{array}{l}0.0867 \\
(0.162)\end{array}$ & $\begin{array}{c}0.101 \\
(0.189)\end{array}$ & & $\begin{array}{l}0.0613 \\
(0.120)\end{array}$ & $\begin{array}{l}0.0465 \\
(0.131)\end{array}$ \\
\hline both_p_gone_abroad & & $\begin{array}{l}-0.268 \\
(0.539)\end{array}$ & $\begin{array}{l}-0.111 \\
(0.606)\end{array}$ & & $\begin{array}{l}-0.179 \\
(0.362)\end{array}$ & $\begin{array}{l}-0.039 \\
(0.339)\end{array}$ \\
\hline only_m_gone_abroad & & $\begin{array}{l}-0.155 \\
(0.577)\end{array}$ & $\begin{array}{l}-0.274 \\
(0.609)\end{array}$ & & $\begin{array}{l}-0.116 \\
(0.435)\end{array}$ & $\begin{array}{r}-0.117 \\
(0.381)\end{array}$ \\
\hline only_d_gone_abroad & & $\begin{array}{l}0.0174 \\
(0.437)\end{array}$ & $\begin{array}{l}0.0523 \\
(0.478)\end{array}$ & & $\begin{array}{l}0.0211 \\
(0.304)\end{array}$ & $\begin{array}{l}0.0826 \\
(0.332)\end{array}$ \\
\hline opn & & & $\begin{array}{l}-0.252 \\
(0.439)\end{array}$ & & & $\begin{array}{l}-0.135 \\
(0.274)\end{array}$ \\
\hline inclined_to_exact_sci & & & $\begin{array}{c}-0.776 \text { ** } \\
(0.368)\end{array}$ & & & $\begin{array}{c}-0.495 * \\
(0.255)\end{array}$ \\
\hline high_believe_in_God & & & $\begin{array}{c}0.176 \\
(0.441)\end{array}$ & & & $\begin{array}{c}0.151 \\
(0.294)\end{array}$ \\
\hline secular & & & $\begin{array}{l}1.371^{* *} \\
(0.612)\end{array}$ & & & $\begin{array}{l}1.034^{* *} \\
(0.421)\end{array}$ \\
\hline indiv_lib_clear_cause_of_progr & & & $\begin{array}{c}1.313^{* * *} \\
(0.506)\end{array}$ & & & $\begin{array}{c}0.994^{* *} \\
(0.407)\end{array}$ \\
\hline accept_or_doubts_about_bribe & & & $\begin{array}{c}0.507 \\
(0.508)\end{array}$ & & & $\begin{array}{c}0.388 \\
(0.331)\end{array}$ \\
\hline only_strong_conn $4 c l \_a c c \_i n$ & & & $\begin{array}{l}0.638 * \\
(0.365)\end{array}$ & & & $\begin{array}{l}0.420 * \\
(0.255)\end{array}$ \\
\hline
\end{tabular}


Table 4. Cont.

\begin{tabular}{|c|c|c|c|c|c|c|}
\hline \multirow{2}{*}{ Variables } & \multicolumn{3}{|c|}{ Logit Regression } & \multicolumn{3}{|c|}{ Poisson Regression with Robust Standard Errors } \\
\hline & (a) & (b) & (c) & (d) & (e) & (f) \\
\hline communist_past_migr_cause & & & $\begin{array}{c}0.946^{* *} \\
(0.392)\end{array}$ & & & $\begin{array}{c}0.677^{* *} \\
(0.285)\end{array}$ \\
\hline injust_in_soc_migr_cause & & & $\begin{array}{c}0.284 \\
(0.370)\end{array}$ & & & $\begin{array}{c}0.163 \\
(0.272)\end{array}$ \\
\hline degrad_work_ethic_migr_cause & & & $\begin{array}{l}-0.551 \\
(0.454)\end{array}$ & & & $\begin{array}{l}-0.385 \\
(0.311)\end{array}$ \\
\hline excesive_bureaucracy_migr_cause & & & $\begin{array}{c}-0.0779 \\
(0.379)\end{array}$ & & & $\begin{array}{c}-0.0253 \\
(0.264)\end{array}$ \\
\hline CONSTANT & $\begin{array}{c}-2.744^{* * *} \\
(0.243)\end{array}$ & $\begin{array}{c}-2.746^{* * *} \\
(0.505)\end{array}$ & $\begin{array}{c}-4.921^{* * *} \\
(1.130) \\
\end{array}$ & $\begin{array}{c}-2.807^{* * *} \\
(0.229)\end{array}$ & $\begin{array}{c}-2.804^{* * *} \\
(0.416)\end{array}$ & $\begin{array}{c}-4.439^{* * *} \\
(0.685)\end{array}$ \\
\hline Observations & 387 & 380 & 380 & 387 & 380 & 380 \\
\hline LR chi2(df)| Wald chi2(df) & 48.38 & 51.58 & 82.51 & 46.08 & 55.94 & 129.07 \\
\hline$d f$ & 1 & 7 & 18 & 1 & 7 & 18 \\
\hline Prob $>$ chi 2 & 0.0000 & 0.0000 & 0.0000 & 0.0000 & 0.0000 & 0.0000 \\
\hline Pseudo R square & 0.1604 & 0.1721 & 0.2753 & 0.1302 & 0.1381 & 0.2119 \\
\hline$A U C(R O C)$ & 0.7402 & 0.7762 & 0.8667 & N/A & $\mathrm{N} / \mathrm{A}$ & N/A \\
\hline
\end{tabular}

Source and Note are the same as in Table 2.

Table 2 contains the raw coefficients used to analyse the influences on the migration intentions after graduation for students in economics from FEAA, UAIC, Iasi.

In the baseline specification (a) or (d), we have included, in this regional model (Table 2), only the core variable clear_eq_migrWEur_pers_val_recog, which remains strong and highly significant along all consecutive scenarios-(a) to (c) and (d) to (f). This variable fully demonstrates that the personal intention to migrate to Western countries for the recognition of personal value is strongly and significantly associated in a positive way with the increase in the likelihood of wanting to migrate abroad.

Besides this core variable, other particular influences are manifested, proving the robustness of this regional model. In the last scenario, (c) or (f), the influence of the variable secular, considered as a measure of the weak public manifestation of faith of each individual (e.g., low frequency of Church attendance) suggests that it is positively and significantly associated with the intention to migrate after graduation. This most comprehensive scenario also confirms the influence of indiv_lib_clear_cause_of_progr. The latter supports an interesting idea, namely, that the students who put a great emphasis on individual liberty, as a prerequisite for economic and social development, are more likely to choose to migrate to Western countries after graduation.

Table 3 contains the raw coefficients used to explore the influences on the migration intentions after graduation for the same category of students, but from Cluj-Napoca. For all consecutive scenarios of this regional model, the core variable clear_eq_migrWEur_pers_val_recog maintained its high level of significance and positive influence. Its coefficients are greater than in the previous regional model (Table 2), and with the same high level of significance, meaning a stronger positive influence on the likelihood to migrate.

Starting with the 2nd scenario, (b) or (e), the variable both_p_gone_abroad started to prove a significant positive influence, exclusively manifested for this regional intellectual community. This suggests that, in this more developed area, an individual with family experience regarding the migration of both parents abroad for more than one year, is more likely to migrate abroad. This finding supports the idea that students with parental migration background may benefit from it as experience, accumulated skills, and particular knowledge, in order to ease their decision to migrate. A less important influence was identified for the cases where only mothers have gone abroad for more than a year, which seems to be positively associated to the likelihood of migrating in Western countries, although with a lower intensity when compared to the previous case when both parents were migrants (both_p_gone_abroad). 
Other positive influences are the ones given by the variables indiv_lib_clear_cause_of_progr and only_strong_conn4cl_acc_in. Therefore, the students with a preference for the clear choice of individual liberty as a determinant of progress, and the idea that the strong connections are the only way to succeed in a career in the native country, are more likely to migrate to Western countries. The variable no_of_sibl becomes relevant only the last scenario, (c) or (f), the corresponding estimations (Table 3) illustrating a negative association, namely as the number of siblings increases, the likelihood of migration intentions decreases.

Table 3 interestingly reveals the negative influence of both private and social manifestation of religious behaviour on the students' intentions to migrate abroad. Hence, the internal religiosity (high_believe_in_God) and the social one (secular) are associated with staying in Romania, rather than migrating abroad. Those who manifest high internal religiosity seem much more likely to intend not to migrate abroad, in contrast with the ones with a social manifestation of religiosity (higher vs lower magnitude and significance for corresponding coefficients). We find this influence explicable in the sense that the students being more religious might think they have a sacred mission in terms of welfare of the community they belong and are so attached to.

Table 4 presents the raw coefficients for analysing the influences on the migration intentions of students who study economics in Sibiu. Along all scenarios, the core variable maintained its high level of significance and positive influence.

Other influences are the ones of the variables secular, indiv_lib_clear_cause_of_progr, communist_past_migr_cause, and only_strong_conn $4 c l \_a c c \_i n$. Their high positive coefficients suggest a considerable positive association with the students' intentions to migrate after graduation. Therefore, the students who experience low Church attendance put a great emphasis on individual liberty as a cause of economic and social progress, believe that only through strong connections could they find a proper job, and consider the communist past the main cause of migration, seem to be more determined to migrate to Western countries after graduation. By contrast, the students with a proper inclination to exact sciences are more likely to stay in Romania after graduation.

The results provided by all regional models (Tables $2-4$ ) confirm the personal value recognition as the main common "ingredient" of influence (proven robustness as sign, magnitude, and significance) for the students' intention to migrate after graduation. Moreover, another common and considerable positive influence is observed for the students who put a great emphasis on individual liberty as an important cause of progress (indiv_lib_clear_cause_of_prog). This might be due to the fact that they intend to act in a rational and self-interested manner in order to satisfy the need for personal fulfilment, with an emphasis on individual freedom. They both are key elements that could either betray a sense of selfishness, at least a psychological one [70] from deterministic thinking or the desire for the pursuit of happiness, and help the others by improving themselves, from an in-depth moral point of view. These results are in line with previous studies indicating the role of meritocracy and individual freedom in the decision to migrate in the future.

In terms of hypothesis validation, $\mathrm{H} 1$ is mostly validated by these regional models. The only exceptions are represented by the drop of the variables corresponding to interpersonal trust and agreeableness due to multicollinearity issues. We consider that $\mathrm{H} 1$ finds the strongest empirical support for all considered models. Therefore, the students who put a great accent on personal value recognition are more likely to migrate after graduation than the ones who did not consider it important for this potential decision. Another variable from $\mathrm{H} 1$ which is empirically proven, although with slight differences in terms of level of significance and magnitude between regional models, is individual liberty. Therefore, freedom-friendly students are more likely to wish to migrate after graduation than the ones who put lower accent on the role of individual liberty in social and economic progress.

Hypothesis $2(\mathrm{H} 2)$ is partially validated. The results are contradictory when considering the regional models. For Iași, $\mathrm{H} 2$ is valid only for external religiosity (secular) meaning that low religious services attenders are more likely to migrate after graduation than high Church-goers. In the case of Cluj-Napoca, H2 is supported by the results, but secular has a different sign, although a much 
lower significance. This means that high believers in God are less likely to migrate than non-believers. Sibiu is also interesting because $\mathrm{H} 2$ is empirically proven only for external religiosity. Hence, the low religious services attenders are more likely to migrate rather than stay in the country of origin than the Church attenders.

The third hypothesis (H3) is validated only for the intergenerational transmission of parental migration experience, the parents' level of education being excluded due to multicollinearity issues. Moreover, $\mathrm{H} 3$ is empirically proven only in the case of the students who study in Cluj-Napoca.

The last hypothesis (H4) is also partially validated by our empirical models. The exceptions are given by the variables excessive_bureaucracy_migr_cause, accept_or_doubts_about_bribe, degrad_work_ethic_migr_cause and injust_in_soc_migr_cause. The students who are dissatisfied by communist reminiscences in society (communist_past_migr_cause) and illegitimate lobby for professional achievement (only_strong_conn4cl_acc_in) are more likely to migrate abroad than the ones who are not dissatisfied by those above. $\mathrm{H} 4$ is not proven at all for the regional model of Iași. For Sibiu, H4 is partially validated for both the variables only_strong_conn4cl_acc_in and communist_past_migr_cause while, for Cluj-Napoca, the only significant influence corresponds to only_strong_conn $4 c l \_a c c \_i n$.

The values for the area under the curve of receiver operating characteristic [71] (AUC (ROC)) in Tables 2-4-scenario (a) are quite high for all specified scenarios. When the regional models explain the clear intention to migrate in the Western countries after graduation only by considering the core variable, namely, the personal value recognition, the ROC values are still high ( 0.7271 for Iași, 0.7536 for Cluj-Napoca, and 0.7402 for Sibiu) to validate it as the main influence having an overwhelming effect on the intention to migrate. In the final scenario-(c), all three regional models have higher ROC values ( 0.7816 for Iași, 0.8073 for Cluj-Napoca, and 0.8667 for Sibiu), which means, at least for the latter two, that they have a good accuracy (ROC $>0.8$ ) as solid argument for their consistency.

When performing both the deviance and Pearson goodness-of-fit tests for the Poisson regression with robust standard errors for the overall model (all 3051 records and the cleaned set of eighteen independent variables filtered using a VIF based approach), we get results (Prob > chi2) with high values ( 1 in both cases), indicating that we cannot reject the hypothesis that data are Poisson distributed. In the case of the logistic regression for the same aforementioned overall model, the Pearson goodness-of-fit test also returns high values $(\sim 0.23)$ indicating that our model fits reasonably well. The skewness test of variables in the overall model rejects the null hypothesis of normality (Pr values below 0.01 in all cases). The skewness values are, in all cases, outside the range of $(-0.5,0.5)$, indicating a moderately or even highly skewed distribution. Still, asymmetry is not a matter of concern, since both the binary logistic regression [72] and the Poisson regression with robust standard errors (the latter as a generalised linear model form of regression analysis) [73] are proven to be robust when using non-normal data.

Both overall regressions reveal, again, the most powerful and significant influence (positive) of the core variable corresponding to the recognition of the personal value and, also, the one of the individual freedom as cause of progress. The secondary influences as significance which result from both overall regressions correspond to the parental role models (both parents gone abroad for at least twelve months-positive), high belief in God (internal religiosity—negative), and family income level (negative, although with a considerably lower magnitude). Finally, we should mention the less significant positive influences associated with the attitudes towards the communist past as an important factor of migration, and the strong connections as the only way to succeed in career in the native country.

Next, we emphasise the main limitations of this paper. Firstly, because we have analysed only the clear intentions to migrate after graduation, we cannot say precisely if they will materialise in the near future. Secondly, because we have observed only the students in economics, further research is needed in order to test if these influences are viable in other professionally heterogeneous contexts. In addition, because these surveyed students usually have fewer responsibilities and duties, they 
may have stronger intentions to leave the country for better jobs or higher standards of living [10]. Moreover, we have not studied, yet, the influence of the respondents' location of origin, by taking into account the criterion of the placement of this location in a territory which, until one hundred years ago, was part of the former Habsburg Empire [74]. This element that could have contributed to profound differences in terms of behaviour, and economic development will be the subject of future research focused on the role of this historical border and its proximity.

\section{Conclusions}

In the context of increased concerns about sustainable policies to reverse the demographic decline of Europe, this paper analyses the influencing factors of post-graduation migration intentions of Romanian students in economics, with evidence from three important university centres. Our main concern was to take into consideration the migration intention, because this is a variable which needs to be analysed for many reasons. The first and most important one is based on the worrying reality that has been manifested in Romanian society for years about the increased exodus of intelligentsia, especially the young highly skilled graduates. The economic, social, and demographic implications of this "brain drain" phenomenon are real challenges for policymakers from the countries that "export" these valuable human capital resources for the sustainability of development in the future. Secondly, as shown in the first section, the intentions to migrate are a solid predictor for the future real decision to go abroad, and understanding the influencing factors behind them is an opportunity for a more in-depth analysis based on economic reasons but, especially, those that are not necessarily pecuniary. Thirdly, we believe that our study opens a broad range of potential underpinnings for further research on a much larger survey of students from several other scientific domains and areas.

Our article is an attempt to fill a gap in the body of literature regarding the understanding of the reasons behind the students' decision to migrate after graduation. In particular, to our knowledge, this is one of the few research studies on how the desire for true meritocracy, along with parental role models and religiosity, are associated with the migration intentions of students in economics. Therefore, this study provides empirical evidence that non-economic motivations are more important than economic ones for the post-graduation intentions to migrate to Western countries of students in economics.

The common findings for all three universities interestingly reveal that students who claim for personal value recognition and who put a great emphasis on personal freedom are more likely to migrate after graduation, compared to the ones who do not put any accent on these features. Hence, the willingness to migrate abroad is basically influenced by attitudes that emphasise a pragmatic desire for recognition, freedom, and taking lives in their own hands in foreign societies, where they expect to successfully achieve subjective goals, than in a corrupt and bureaucratic one.

The rest of the significant influences are particular for each university, demonstrating heterogeneous attitudes and beliefs, depending on each region's economic conditions and perspectives about the labour market, jobs and salaries, infrastructure, and openness to Western Europe, different mentalities, historical past, or even ethnic composition.

Author Contributions: Conceptualisation, A.-P.P., D.H., A.A.M., E.L.C., G.B., R.D.B. and D.A.; Data curation, A.-P.P., D.H., A.A.M. and D.A.; Formal analysis, A.-P.P., D.H., A.A.M. and E.L.C.; Investigation, A.-P.P., D.H., E.L.C., G.B. and R.D.B.; Methodology, A.-P.P., D.H., A.A.M., E.L.C., G.B. and R.D.B.; Resources, A.-P.P., D.H., A.A.M., E.L.C., G.B., R.D.B. and D.A.; Software, A.-P.P., D.H., A.A.M. and D.A.; Supervision, A.-P.P. and D.A.; Validation, A.-P.P., D.H., E.L.C. and D.A.; Visualisation, A.-P.P., D.H. and D.A.; Writing-original draft, A.-P.P., D.H. and E.L.C.; Writing-review \& editing, A.-P.P., D.H., A.A.M., E.L.C., G.B., R.D.B. and D.A.

Funding: This research received no external funding.

Acknowledgments: We thank all the students who participated in this study and all the staff of the faculties who helped to distribute and collect the questionnaires.

Conflicts of Interest: The authors declare no conflict of interest. 


\section{References}

1. Hinks, T.; Davies, S. Intentions to Return: Evidence from Romanian Migrants; World Bank Group WP: Washington, DC, USA, 2015; Volume 7166, p. 2. Available online: https://openknowledge.worldbank. org/bitstream/handle/10986/21386/WPS7166.pdf (accessed on 27 August 2018).

2. World Bank. From Uneven Growth to Inclusive Development: Romania's Path to Shared Prosperity; World Bank: Washington, DC, USA, 2018; pp. 2-3, ISBN 978-1-4648-1317-7.

3. Cairns, D. 'I Wouldn't Stay Here': Economic Crisis and Youth Mobility in Ireland. Int. Migr. 2014, 52, $236-249$. [CrossRef]

4. Cairns, D.; Smyth, J. I Wouldn't Mind Moving Actually: Exploring Student Mobility in Northern Ireland. Int. Migr. 2011, 49, 135-161. [CrossRef]

5. Mosneaga, A.; Winther, L. Emerging Talents? International Students before and After their Career Start in Denmark. Popul. Space Place 2013, 19, 181-195. [CrossRef]

6. Docquier, F. Brain Drain and Inequality across Nations; IZA Discussion Paper No. 2440; IZA: Bonn, Germany, 2006; Volume 2440, pp. 1-38.

7. Roman, M.; Vasilescu, M.D. Explaining the Migration Intentions of Romanian Youth: Are Teenegers Different? Rom. Stat. Rev. 2016, 4, 69-86.

8. Gottlieb, P.D. Labor Supply and the "Brain Drain": Signs from Census 2000; The Brookings Institution: Washington, DC, USA, 2014. Available online: https:/ /www.brookings.edu/wp-content/uploads/2016/06/ 20040116_Gottlieb.pdf (accessed on 3 August 2018).

9. Docquier, F.; Peri, G.; Ruyssen, I. The Cross-Country Determinants of Potential and Actual Migration. Int. Migr. Rev. 2014, 48, S37-S99. [CrossRef]

10. Van Mol, C. Migration Aspirations of European Youth in Times of Crisis. J. Youth Stud. 2016, 19, 1303-1320. [CrossRef]

11. Bilecen, B.; Faist, T. International Doctoral Students as Knowledge Brokers: Reciprocity, Trust and Solidarity in Transnational Networks. Glob. Netw. 2015, 15, 217-235. [CrossRef]

12. Gaule, P.; Piacentini, M. Chinese Graduate Students and US Scientific Productivity. Rev. Econ. Stat. 2013, 95, 698-701. [CrossRef]

13. Vincent-Lancrin, S. Student Mobility, Internationalisation of Higher Education and Skilled Migration; World Migration Report 2008; International Organisation for Migration: Genève, Switzerland, 2008.

14. Eichhorst, W.; Hinte, H.; Rinne, U. Youth Unemployment in Europe: What to Do about It; IZA Policy Paper; IZA: Bonn, Germany, 2013; Volume 65, pp. 1-17.

15. He, Z.; Zhai, G.; Asami, Y.; Tsuchida, S. Migration Intentions and their Determinants: Comparison of College Students in China and Japan. Asian Pac. Migr. J. 2015, 25, 62-84. [CrossRef]

16. Otrachshenko, V.; Popova, O. Life (Dis)satisfaction and the Intention to Migrate: Evidence from Central and Eastern Europe. J. Soc.-Econ. 2014, 48, 40-49. [CrossRef]

17. Hadler, M. Intentions to Migrate within the European Union: A Challenge for Simple Economic Macro-Level Explanations. Eur. Soc. 2006, 8, 111-140. [CrossRef]

18. Van Dalen, H.; Henkens, K. Emigration Intentions: Mere Words or True Plans? Explaining International Migration Intentions and Behavior. 2008. Available online: https:/ / ssrn.com/abstract=1153985 (accessed on 20 August 2018).

19. Cairns, D.; Growiec, K.; Smyth, J. Spatial reflexivity and undergraduate transitions in the Republic of Ireland after the Celtic Tiger. J. Youth Stud. 2012, 15, 841-857. [CrossRef]

20. Williams, A.M.; Jephcote, C.; Janta, H.; Li, G. The Migration Intentions of Young Adults in Europe: A Comparative, Multilevel Analysis. Popul. Space Place 2017, 24, e2123. [CrossRef]

21. De Jong, G.F. Expectations, Gender, and Norms in Migration Decision-Making. Popul. Stud. 2000, 54, $307-319$. [CrossRef] [PubMed]

22. Burda, M.; Hardle, W.; Muller, M.; Werwatz, A. Semiparametric Analysis of German East-West Migration Intentions: Facts and Theory. J. Appl. Econ. 1998, 13, 525-541. [CrossRef]

23. Ivlevs, A.; King, R.M. Family Migration Capital and Migration Intentions. J. Fam. Econ. Issues 2012, 33, 118-129. [CrossRef]

24. Lee, E.S. A Theory of Migration. Demography 1966, 3, 47-57. [CrossRef] 
25. Mazarrol, T.; Soutar, G. Push-pull Factors Influencing International Student Destination Choice. Int. J. Educ. Manag. 2002, 16, 82-90. [CrossRef]

26. Marchiori, L.; Shen, I.L.; Docquier, F. Brain Drain in Globalization: A General Equilibrium Analysis from the Sending Countries' Perspective. Econ. Inq. 2013, 51, 1582-1602. [CrossRef]

27. Machin, S.; Salvanes, K.G.; Pelkonen, P. Education and Mobility. J. Eur. Econ. Assoc. 2012, 10, 417-450. [CrossRef]

28. Malamud, O.; Wozniak, A. The Impact of College on Migration: Evidence from the Vietnam Generation. J. Hum. Res. 2012, 47, 913-950. [CrossRef]

29. Halfacree, K.A. Utopian Imagination in Migration's Terra Incognita? Acknowledging the Non-Economic Worlds of Migration Decision-Making. Popul. Space Place 2004, 10, 239-253. [CrossRef]

30. Frieze, I.H.; Boneva, B.S.; Šarlija, N.; Horvat, J.; Ferligoj, A.; Kogovšek, T.; Miluska, J.; Popova, L.; Korobanova, J.; Sukhareva, N.; et al. Psychological Differences in Stayers and Leavers: Emigration Desires in Central and Eastern European University Students. Eur. Psychol. 2004, 9, 15-23. [CrossRef]

31. Li, M.; Frieze, I.H.; Horvat, J.; Mijoč, J.; Olson, J.E. Reasons for Leaving Home: Comparing Predictors of Wanting to Migrate and Travel in 185 Croatian Undergraduates. Migracijske i Etničke Teme 2012, 28, 7-27.

32. Cebula, R.J. Internal Migration Determinants: Recent Evidence. Int. Adv. Econ. Res. 2005, 11, $267-274$. [CrossRef]

33. Asis, M.; Battistella, G. The Filipino Youth and the Employment-Migration Nexus; UNICEF Philippines and Scalabrini Migration Center: Makati, Philippines; Quezon, Philippines, 2013; pp. 1-123, ISBN 978-971-529-072-2.

34. Geddie, K. The Transnational Ties That Bind: Relationship Considerations for Graduating International Science and Engineering Research Students. Popul. Space Place 2013, 19, 196-208. [CrossRef]

35. Skachkova, P. Academic Careers of Immigrant Women Professors in the U.S. High. Educ. 2007, 53, 697-738. [CrossRef]

36. Epstein, G.S.; Gang, I.N. Migration and Culture. In Migration and Culture (Frontiers of Economics and Globalization); Epstein, G.S., Gang, I.N., Eds.; Emerald Group Publishing Limited: Bingley, UK, 2010; Volume 8, pp. 1-21. ISBN 978-0-85724-153-5.

37. Fitzgerald, J.; Leblang, D.; Teets, J. Defying the Law of Gravity: The Political Economy of International Migration. World Politics 2014, 66, 406-445. [CrossRef]

38. Nifo, A.; Vecchione, G. Do Institutions Play a Role in Skilled Migration? The Case of Italy. Reg. Stud. 2014, 48, 1628-1649. [CrossRef]

39. Cook, J.; Dwyer, P.; Waite, L. The Experiences of Accession 8 migrants in England: Motivations, Work and Agency. Int. Migr. 2011, 49, 54-79. [CrossRef]

40. Bygnes, S. Are They Leaving Because of the Crisis? The Sociological Significance of Anomie as a Motivation for Migration. Sociology 2017, 51, 258-273. [CrossRef]

41. Ashby, N.J. Freedom and International Migration. South. Econ. J. 2010, 77, 49-62. [CrossRef]

42. Yakovlev, P.; Steinkopf, T. Can Economic Freedom Cure Medical Brain Drain? J. Priv. Enterp. 2014, 29, 97-117.

43. Mulholland, S.E.; Hernández-Julián, R. Does Economic Freedom Lead to Selective Migration by Education? J. Reg. Anal. Policy 2013, 43, 65-81.

44. Cebula, R.J.; Foley, M.; Hall, J.C. Freedom and Gross in-Migration: An Empirical Study of the Post-Great Recession Experience. J. Econ. Financ. 2016, 40, 402-420. [CrossRef]

45. Tilly, C. Trust Networks in Transnational Migration. Sociol. Forum 2007, 22, 3-24. [CrossRef]

46. Frieze, I.H.; Hansen, S.B.; Boneva, B. The Migrant Personality and College Students' Plans for Geographic Mobility. J. Environ. Psychol. 2006, 26, 170-177. [CrossRef]

47. Canache, D.; Hayes, M.; Mondak, J.J.; Wals, S.C. Openness, Extraversion and the Intention to Emigrate. J. Res. Personal. 2013, 47, 351-355. [CrossRef]

48. Boneva, B.; Frieze, I.H.; Ferligoj, A.; Jarosova, E.; Pauknerová, D.; Orgocka, A. Achievement, Power, and Affiliation Motives as Clues to (E)migration Desires. Eur. Psychol. 1998, 3, 247-254. [CrossRef]

49. Jokela, M. Personality Predicts Migration within and between U.S. States. J. Res. Personal. 2009, 43, 79-83. [CrossRef]

50. Tabor, A.S.; Milfont, T.L.; Ward, C. The Migrant Personality Revisited: Individual Differences and International Mobility Intentions. N. Z. J. Psychol. 2015, 44, 89-95. 
51. Polek, E.; Van Oudenhoven, J.P.; Berge, J.M.F.T. Evidence for a "Migrant Personality": Attachment Styles of Poles in Poland and Polish Immigrants in the Netherlands. J. Immigr. Refug. Stud. 2011, 9, 311-326. [CrossRef]

52. Paulauskaitè, E.; Šeibokaitè, E.; Endriulaitienè, A. Big Five Personality Traits Linked with Migratory Intentions in Lithuanian Student Sample. Int. J. Psychol. Biopsychol. Approach 2010, 7, 41-58.

53. Huang, T.; Chi, S.; Lawler, J. The Relationship between Expatriates' Personality Traits and Their Adjustment to International Assignments. Int. J. Hum. Res. Manag. 2005, 16, 1656-1670. [CrossRef]

54. Docquier, F.; Tansel, A.; Turati, R. Do Emigrants Self-Select Along Cultural Traits?: Evidence from the MENA Countries; CESifo Working Paper; CESifo: Munich, Germany, 2017; Volume 6777, pp. 1-53.

55. Van Dijck, J.; Feijten, P.; Boyle, P. Migration and Religion in Scotland. A Study on the Influence of Religion on Migration Behaviour. LSCS Research Working Paper 8.0; 2010. Available online: https:/ / calls.ac.uk/wpcontent/uploads/WP8-van-Dijck-Feiijten-Boyle.pdf (accessed on 13 August 2018).

56. Aleksynska, M.; Chiswick, B.R. Religiosity and Migration: Travel into One's Self versus Travel across Cultures; IZA Discussion Papers; IZA: Bonn, Germany, 2011; Volume 5724, pp. 1-38.

57. Hoffman, S.; Marsiglia, F.F.; Ayers, S.L. Religiosity and Migration Aspirations among Mexican Youth. J. Int. Migr. Integr. 2015, 16, 173-186. [CrossRef] [PubMed]

58. Massey, D.S. Social Structure, Household Strategies and the Cumulative Causation of Migration. Popul. Index 1990, 56, 3-26. [CrossRef] [PubMed]

59. Menjívar, C. Fragmented Ties: Salvadoran Immigrant Networks in America, 1st ed.; University of California Press: Berkeley, CA, USA, 2000; ISBN 0520222113.

60. De Jong, G.F.; Richter, K.; Isarabhakdi, P. Gender, Values, and Intentions to Move in Rural Thailand. Int. Migr. Rev. 1996, 30, 748-770. [CrossRef] [PubMed]

61. Munafò, M.R.; Smith, G.D. Robust Research Needs Many Lines of Evidence. Nature 2018, 553, $399-401$. [CrossRef] [PubMed]

62. Bewick, V.; Cheek, L.; Ball, J. Review. Statistics Review 14: Logistic Regression. Crit. Care 2005, 9, 112-118. [CrossRef] [PubMed]

63. Long, S.J.; Freese, J. Regression Models for Categorical Dependent Variables Using Stata, 3rd ed.; Stata Press: College Station, TX, USA, 2014; p. 390, ISBN 1-59718-111-0.

64. Stillwell, J.; Duke-Williams, O.; Dennett, A. Technologies for Migration and Commuting Analysis: Spatial Interaction Data Applications; IGI Global: Hershey, PA, USA, 2010; pp. 261-279, ISBN 978-1615207558.

65. Zou, G. A Modified Poisson Regression Approach to Prospective Studies with Binary Data. Am. J. Epidemiol. 2004, 159, 702-706. [CrossRef] [PubMed]

66. Plopeanu, A.-P.; Homocianu, D.; Necula, C.-V. A Study on the Emigration Enablers of the Romanian Students in Theology. Revista Românească Pentru Educaţie Multidimensională 2018, 10, 180-197. [CrossRef]

67. Massey, D.S.; Arango, J.; Hugo, G.; Kouaouci, A.; Pellegrino, A.; Taylor, J.E. Theories of International Migration: A Review and Appraisal. Popul. Dev. Rev. 1993, 19, 431-466. [CrossRef]

68. Salmerón, R.; García, C.B.; García, J. Variance Inflation Factor and Condition Number in Multiple Linear Regression. J. Stat. Comput. Simul. 2018, 88, 2365-2384. [CrossRef]

69. Midi, H.; Sarkar, S.K.; Rana, S. Collinearity Diagnostics of Binary Logistic Regression Model. J. Int. Math. 2010, 13, 253-267. [CrossRef]

70. Hertel, G.; Fiedler, K. Fair and Dependent versus Egoistic and Free: Effects of Semantic and Evaluative Priming on the 'Ring Measure of Social Values'. Eur. J. Soc. Psychol. 1998, 28, 49-70. [CrossRef]

71. Jiménez-Valverde, A. Insights into the Area under the Receiver Operating Characteristic Curve (AUC) as a Discrimination Measure in Species Distribution Modelling. Glob. Ecol. Biogeogr. 2012, 21, 498-507. [CrossRef]

72. Moawed, S.A.; Osman, M.M. The Robustness of Binary Logistic Regression and Linear Discriminant Analysis for the Classification and Differentiation between Dairy Cows and Buffaloes. Int. J. Stat. Appl. 2017, 7, 304-310. [CrossRef] 
73. St-Pierre, A.P.; Shikon, V.; Schneider, D.C. Count data in biology—Data transformation or model reformation? Ecol. Evol. 2018, 8, 3077-3085. [CrossRef] [PubMed]

74. Becker, S.O.; Boeckh, K.; Heinz, C.; Woessmann, L. The Empire is Dead, long live the Empire! Long-run persistence of trust and corruption in the bureaucracy. Econ. J. 2016, 126, 40-74. [CrossRef]

(c) 2018 by the authors. Licensee MDPI, Basel, Switzerland. This article is an open access article distributed under the terms and conditions of the Creative Commons Attribution (CC BY) license (http://creativecommons.org/licenses/by/4.0/). 